\title{
Dermatomyositis. Diagnostic and therapeutic recommendations of the Polish Dermatological Society
}

\section{Zapalenie skórno-mięśniowe. Rekomendacje diagnostyczno-terapeutyczne Polskiego Towarzystwa Dermatologicznego}

\author{
Adam Reich', Anna Lis-Święty², Dorota Krasowska ${ }^{3}$, Joanna Maj ${ }^{4}$, Joanna Narbuttt ${ }^{5}$ Anna Sysa-Jędrzejowska ${ }^{6}$, \\ Anna Wojas-Pelc ${ }^{7}$, Anna Woźniacka ${ }^{6}$, Lidia Rudnicka ${ }^{8}$

\begin{abstract}
'Department of Dermatology, Institute of Medical Sciences, Medical College of Rzeszow University, Poland ${ }^{3}$ Department of Dermatology, Silesian Medical University, Katowice, Poland

${ }^{4}$ Department of Dermatology, Venereology and Allergology, Wroclaw Medical University, Poland

${ }^{5}$ Department of Dermatology, Pediatric and Oncological Dermatology, Medical University of Lodz, Poland ${ }^{6}$ Department of Dermatology and Venereology, Medical University of Lodz, Poland

${ }^{7}$ Department of Dermatology and Venereology, Jagiellonian University Medical College, Krakow, Poland ${ }^{8}$ Department of Dermatology, Warsaw Medical University, Poland
\end{abstract} \\ 2Department of Dermatology, Venereology and Pediatric Dermatology, Medical University in Lublin, Poland
}

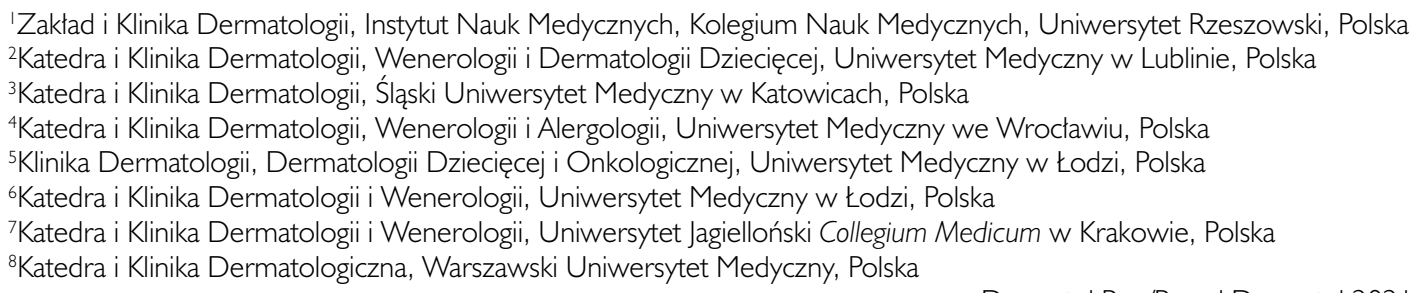

CORRESPONDING AUTHOR/ ADRES DO KORESPONDENCJI: prof. dr hab. n. med. Adam Reich Zakład i Klinika Dermatologii Uniwersytet Rzeszowski ul. Szopena 2 35-055 Rzeszów tel.: +48605076 722 e-mail: adi_medicalis@go2.pl

\begin{abstract}
Dermatomyositis is an autoimmune disease characterized by skin lesions and/or symptoms of myositis. In addition to the so-called classic dermatomyositis the following forms of dermatomyositis are distinguished based on the clinical presentation: pediatric, paraneoplastic, drug-induced and amyopathic. A number of disease-specific autoantibodies are identified in dermatomyositis (including anti-Mi2, anti-TIF1, anti-NXP2, anti-SAE or anti-MDA5), presence of which may be associated with a specific clinical phenotype. The diagnosis of the severity of muscle involvement is currently based mainly on physical examination, deviations in results of laboratory investigations, electromyographic examination and imaging examination, mainly with the use of magnetic resonance imaging. Systemic glucocorticosteroids administered as monotherapy or in combination with other immunosuppressants remain the mainstay of dermatomyositis treatment, and in the absence of satisfactory improvement, intravenous immunoglobulins are used. In addition, in case of interstitial lung disease, the use of cyclophosphamide may be necessary. The choice of a therapy, as well as the rate of dose reduction, depend on the dynamics of the disease, symptoms, diagnosed immunological disorders, as well as comorbidities and the drugs used. Each diagnostic and therapeutic decision must take into account the individual clinical data of the patient and current scientific reports.
\end{abstract}




\section{STRESZCZENIE}

Zapalenie skórno-mięśniowe jest chorobą autoimmunologiczną cechującą się obecnością zmian skórnych i/lub objawów zapalenia mięśni. Poza tzw. postacią klasyczną na podstawie obrazu klinicznego wyróżnia się jeszcze następujące postaci zapalenia skórno-mięśniowego: dziecięcą, paraneoplastyczną, indukowaną lekami oraz postać bez zajęcia mięśni. W przebiegu zapalenia skórno-mięśniowego identyfikuje się szereg autoprzeciwciał (m.in. anty-Mi2, anty-TIF1, anty-NXP2, anty-SAE lub anty-MDA5), których obecność może być powiązana z określonym fenotypem klinicznym. Diagnostykę nasilenia zajęcia mięśni obecnie opiera się głównie na badaniu fizykalnym, odchyleniach $w$ badaniach laboratoryjnych, badaniu elektromiograficznym oraz badaniach obrazowych, przede wszystkim przy użyciu rezonansu magnetycznego. Podstawą leczenia zapalenia skórno-mięśniowego są podawane ogólnie glikokortykosteroidy w monoterapii lub $\mathrm{w}$ połączeniu $\mathrm{z}$ innymi lekami immunosupresyjnymi, a w przypad$\mathrm{ku}$ braku zadowalającej poprawy immunoglobuliny dożylne. Ponadto w przypadku śródmiąższowej choroby płuc konieczne może być zastosowanie cyklofosfamidu. Wybór terapii i szybkość redukcji dawek zależą od dynamiki procesu chorobowego, objawów, stwierdzanych zaburzeń immunologicznych, a także chorób współistniejących oraz stosowanych leków. Każda decyzja diagnostyczno-terapeutyczna musi uwzględniać sytuację kliniczną pacjenta oraz bieżące doniesienia naukowe.

Key words: dermatomyositis, idiopathic inflammatory myopathies, autoimmune diseases of connective tissue, treatment.

Słowa kluczowe: zapalenie skórno-mięśniowe, idiopatyczne miopatie zapalne, autoimmunologiczne choroby tkanki łącznej, leczenie.

\section{INTRODUCTION}

Dermatomyositis (DM) along with polymyositis (PM) and inclusion body myositis (IBM) are classified as idiopathic inflammatory myopathies (IIM). Dermatomyositis is an autoimmune disease characterized by the presence of skin lesions and symptoms of myositis of various severity. The disease is divided into a number of varieties: the so-called classic DM, juvenile dermatomyositis (JDM), paraneoplastic dermatomyositis (PDM), drug-induced dermatomyositis (DIDM), clinically amyopathic dermatomyositis (CADM; Latin: dermatomyositis siné myositis), and the oligosymptomatic form in relation to muscle involvement (hypomyopathic dermatomyositis, HDM) [1]. Dermatomyositis is a rare disease, but it is the most common IIM in all age groups. The prevalence of DM is estimated at 5-11 cases per 100,000 people. There are two high incidence peaks: the first between the ages of 5 and 15 and the second between the ages of 50 and 60 years [1].

\section{CLINICAL PRESENTATION}

In 2017, experts from the European League Against Rheumatism (EULAR) together with the

\section{WPROWADZENIE}

Zapalenie skórno-mięśniowe (dermatomyositis - DM) wraz z zapaleniem wielomięśniowym (polymyositis PM) oraz wtrętowym zapaleniem mięśni (inclusion body myositis - IBM) jest zaliczane do tzw. idiopatycznych miopatii zapalnych (idiopathic inflammatory myopathies - IIM). Zapalenie skórno-mięśniowe jest schorzeniem o podłożu autoimmunologicznym cechującym się obecnością zmian skórnych i różnie nasilonych objawów zapalenia mięśni. Wyróżnia się szereg jego odmian: tzw. klasyczną postać DM, postać dziecięcą DM (juvenile dermatomyositis - JDM), postać paraneoplastyczną DM (paraneoplastic dermatomyositis - PDM), DM indukowane lekami (drug-induced dermatomyositis - DIDM), DM bez zajęcia mięśni (clinically amyopathic dermatomyositis - CADM; łac. dermatomyositis siné myositis) oraz postać skąpoobjawową w przypadku dolegliwości mięśniowych (hypomyopatic dermatomyositis - HDM) [1]. Zapalenie skórno-mięśniowe jest rzadką jednostką chorobową, jednak stanowi najczęściej występującą IIM we wszystkich przedziałach wiekowych. Rozpowszechnienie DM szacuje się na 5-11 przypadków na 100000 osób. Obserwuje się dwa szczyty zachorowań: pierwszy między 5. a 15. rokiem życia oraz drugi w wieku 50-60 lat [1]. 
American College of Rheumatology (ACR) developed new IIM classification criteria, including DM criteria that may be helpful in diagnosing patients with symptoms of inflammatory myopathy (table 1) [2]. According to the proposed classification, the diagnosis of IIM is probable if the patient scores $>6.7$ points with muscle damage confirmed by bi-

\section{OBRAZ KLINICZNY}

W 2017 roku eksperci Europejskiej Ligi Przeciw Reumatyzmowi (European League Against Rheumatism - EULAR) wspólnie z ekspertami Amerykańskiego Towarzystwa Reumatologicznego (American College of Rheumatology - ACR) opracowali nowe kryteria klasyfikacyjne IIM, w tym kryteria DM, które mogą być po-

Table I. European League Against Rheumatism (EULAR) with the American College of Rheumatology (ACR) classification criteria for idiopathic inflammatory myopathies [2]

\begin{tabular}{llc} 
Variable & $\begin{array}{c}\text { Score in case of } \\
\text { muscle biopsy }\end{array}$ & $\begin{array}{c}\text { Score with no } \\
\text { muscle biopsy }\end{array}$ \\
Onset between the age of I 8 and 40 years & 1.5 & 1.3 \\
\hline Onset at the age of $>40$ years & 2.2 & 2.1 \\
\hline Heliotrope symptom & 3.2 & 3.1 \\
\hline Gottron's papules & 2.7 & 2.1 \\
\hline Gottron's symptom & 3.7 & 3.3 \\
\hline More pronounced weakness of neck flexors than extensors & 1.6 & 1.9 \\
\hline Objective symmetrical reduction of strength of proximal muscles in upper extremities & 0.7 & 0.7 \\
\hline Objective symmetrical reduction of strength of proximal muscles in lower extremities & 0.5 & 0.8 \\
\hline Proximal muscles in lower extremities weaker than distal ones & 1.2 & 0.9 \\
\hline Dysphagia or disorders of peristalsis of the esophagus & 0.6 & 0.7 \\
\hline Anti-jo-I antibodies & 3.8 & 3.9 \\
\hline Increased activity of CPK or LDH, or serum AST or ALT & 1.4 & 1.3 \\
\hline Inflammatory infiltration composed of mononuclear cells within the endomysium & 1.7 & - \\
\hline Perivascular and perimuscular infiltrations composed of mononuclear cells & 1.2 & - \\
\hline Peripheral vacuolization of muscle cells & 3.1 & - \\
\hline Peripheral atrophy of muscle fibers & 1.9 & - \\
\hline
\end{tabular}

ALT - alanine aminotransferase, AST - aspartate aminotransferase, CPK - creatine phosphate kinase, LDH - lactic acid dehydrogenase.

Tabela I. Kryteria klasyfikacyjne idiopatycznych miopatii zapalnych European League Against Rheumatism (EULAR) wspólnie z American College of Rheumatology (ACR) [2]

\begin{tabular}{|c|c|c|}
\hline Zmienne & $\begin{array}{c}\text { Punktacja } \\
\text { w przypadku } \\
\text { biopsji mięśni }\end{array}$ & $\begin{array}{c}\text { Punktacja bez } \\
\text { wykonania biopsji } \\
\text { mięśni }\end{array}$ \\
\hline Wiek zachorowania między 18. a 40. rokiem życia & 1,5 & 1,3 \\
\hline Wiek zachorowania $>40$ lat & 2,2 & 2,1 \\
\hline Objaw heliotropu & 3,2 & 3,1 \\
\hline Grudki Gottrona & 2,7 & 2,1 \\
\hline Objaw Gottrona & 3,7 & 3,3 \\
\hline Większe osłabienie siły zginaczy szyi niż prostowników & 1,6 & 1,9 \\
\hline Obiektywne symetryczne osłabienie sily proksymalnych mięśni kończyn górnych & 0,7 & 0,7 \\
\hline Obiektywne symetryczne osłabienie sily proksymalnych mięśni kończyn dolnych & 0,5 & 0,8 \\
\hline Proksymalne mięśnie kończyn dolnych słabsze niż mięśnie dystalne & 1,2 & 0,9 \\
\hline Dysfagia lub zaburzenia perystaltyki przełyku & 0,6 & 0,7 \\
\hline Przeciwciała anty-Jo-I & 3,8 & 3,9 \\
\hline Podniesiona aktywność CPK lub LDH, lub AST, lub ALT w surowicy & 1,4 & 1,3 \\
\hline Naciek zapalny złożony z komórek jednojądrzastych w obrębie endomysium & 1,7 & - \\
\hline Nacieki okołonaczyniowe i okołomięśniowe złożone z komórek jednojądrzastych & 1,2 & - \\
\hline Obwodowa wakuolizacja komórek mięśniowych & 3,1 & - \\
\hline Obwodowy zanik włókien mięśniowych & 1,9 & - \\
\hline
\end{tabular}

ALT - aminotransferaza alaninowa, AST - aminotransferaza asparaginowa, CPK - kinaza fosfokreatynowa, LDH - dehydrogenaza kwasu mlekowego. 
Table 2. Antibodies specific for dermatomyositis and the most common clinical features associated with them

\begin{tabular}{|c|c|c|}
\hline Antibody & Autoantigen & Phenotype \\
\hline $\begin{array}{l}\text { Anti-MDA5 } \\
\text { (anti- } \\
\text { CADM- 140) }\end{array}$ & $\begin{array}{l}\text { Melanoma } \\
\text { differentiation- } \\
\text { associated protein } 5\end{array}$ & $\begin{array}{l}\text { Skin lesions: erythematous spots and papules on the palmar side of the metacarpophalangeal } \\
\text { and interphalangeal joints, "mechanic's hand", ulcers } \\
\text { Interstitial lung disease } \\
\text { Poor prognosis }\end{array}$ \\
\hline Anti-Mi-2 & $\begin{array}{l}\text { Nucleosome } \\
\text { remodeling deacetylase } \\
\text { complex (NuRD) }\end{array}$ & $\begin{array}{l}\text { Dermatological symptoms: Gottron's papules, heliotropic rash, scarf symptom, V-neck symptom } \\
\text { Photosensitivity } \\
\text { A fairly good response to treatment }\end{array}$ \\
\hline Anti-NXP2 & $\begin{array}{l}\text { Nuclear matrix protein } \\
2 \text { (NXP-2) }\end{array}$ & $\begin{array}{l}\text { Calcinosis } \\
\text { Muscle weakness } \\
\text { Muscle spasms } \\
\text { Polyarthritis } \\
\text { Dysphagia }\end{array}$ \\
\hline Anti-SAE & $\begin{array}{l}\text { Small ubiquitin-like } \\
\text { modifier I activating } \\
\text { enzyme (SUMO-I) }\end{array}$ & $\begin{array}{l}\text { Dermatological symptoms: heliotropic rash, Gottron's symptom, scarf symptom, V-neck } \\
\text { symptom, periungual erythema } \\
\text { Mild muscle inflammation } \\
\text { Dysphagia }\end{array}$ \\
\hline Anti-SRP & $\begin{array}{l}\text { Signal recognition } \\
\text { particle }\end{array}$ & $\begin{array}{l}\text { Severe course of DM } \\
\text { Poor response to treatment }\end{array}$ \\
\hline $\begin{array}{l}\text { Anty-TIFI- } \gamma \\
\text { (anty-p I 55) }\end{array}$ & $\begin{array}{l}\text { Transcription } \\
\text { intermediary factor I- } \gamma\end{array}$ & $\begin{array}{l}\text { Dermatological symptoms: erythematous changes, scarf symptom, V-neck symptom, } \\
\text { "holster symptom", periungual erythema, poikiloderma } \\
\text { Increased frequency of malignant tumors }\end{array}$ \\
\hline
\end{tabular}

Tabela 2. Przeciwciała swoiste dla zapalenia skórno-mięśniowego i związane z nimi najczęstsze cechy kliniczne

\begin{tabular}{|c|c|c|}
\hline Przeciwciało & Autoantygen & Fenotyp \\
\hline $\begin{array}{l}\text { Anty-MDA5 } \\
\text { (anty- } \\
\text {-CADM-140) }\end{array}$ & $\begin{array}{l}\text { Białko typu } 5 \text { związane } \\
\text { z rozwojem czerniaka } \\
\text { (melanoma differentiation- } \\
\text { associated protein 5) }\end{array}$ & $\begin{array}{l}\text { Zmiany skórne: rumieniowe plamy i grudki po stronie dłoniowej stawów } \\
\text { śródręcznopaliczkowych i międzypaliczkowych, „ręka mechanika”, owrzodzenia } \\
\text { Choroba śródmiąższowa płuc } \\
\text { Złe rokowanie }\end{array}$ \\
\hline Ani-Mi-2 & $\begin{array}{l}\text { Nucleosome remodeling } \\
\text { deacetyalse complex } \\
\text { (NuRD) }\end{array}$ & $\begin{array}{l}\text { Objawy skórne: grudki Gottrona, osutka heliotropowa, objaw szala, objaw V } \\
\text { Fotowrażliwość } \\
\text { Dość dobra odpowiedź na leczenie }\end{array}$ \\
\hline Anty-NXP2 & $\begin{array}{l}\text { Białko macierzy jądrowej } \\
\text { NXP-2 (nuclear matrix } \\
\text { protein 2) }\end{array}$ & $\begin{array}{l}\text { Wapnica } \\
\text { Osłabienie sily mięśniowej } \\
\text { Przykurcze mięśni } \\
\text { Zapalenie wielostawowe } \\
\text { Dysfagia }\end{array}$ \\
\hline Anty-SAE & $\begin{array}{l}\text { Enzym aktywujący SUMO-I } \\
\text { (small ubiquitin-like modifier I } \\
\text { activating enzyme) }\end{array}$ & $\begin{array}{l}\text { Objawy skórne: osutka heliotropowa, objaw Gottrona, objaw szala, objaw V, rumień } \\
\text { okołopaznokciowy } \\
\text { Zapalenie mięśni o łagodnym przebiegu } \\
\text { Dysfagia }\end{array}$ \\
\hline Anty-SRP & $\begin{array}{l}\text { Cząsteczka rozpoznająca } \\
\text { sygnał (signal recognition } \\
\text { particle) }\end{array}$ & $\begin{array}{l}\text { Ciężki przebieg DM } \\
\text { Zła odpowiedź na leczenie }\end{array}$ \\
\hline $\begin{array}{l}\text { Anty-TIF I- } \gamma \\
\text { (anty-p| 55) }\end{array}$ & $\begin{array}{l}\text { Czynnik transkrypcyjny } \\
\text { TIFI- } \gamma(\text { transcription } \\
\text { intermediary factor } 1-\gamma)\end{array}$ & $\begin{array}{l}\text { Objawy skórne: zmiany rumieniowe, objaw szala, objaw V, objaw kabury, rumień } \\
\text { okołopaznokciowy, poikiloderma } \\
\text { Zwiększona częstość występowania nowotworów złośliwych }\end{array}$ \\
\hline
\end{tabular}

opsy, or $>5.5$ points without muscle biopsy. The diagnosis of IIM is certain if the patient scores $>8.7$ and $>7.5$ points, respectively, according to the score assigned to each symptom [2]. Diagnosis of DM is based on the above criteria and the presence of at least one criterion of skin lesions listed in table 1 . If a patient has skin lesions typical of DM, a muscle biopsy is not required to establish the diagnosis. mocne $\mathrm{w}$ diagnozowaniu pacjentów z objawami miopatii zapalnych (tab. 1) [2]. Zgodnie z zaproponowaną klasyfikacją rozpoznanie IIM jest prawdopodobne, jeśli pacjent uzyska $>6,7$ pkt w przypadku potwierdzenia uszkodzenia mięśnia $\mathrm{w}$ biopsji, lub > 5,5 pkt, jeżeli biopsja mięśnia nie została przeprowadzona. Rozpoznanie IIM jest pewne, gdy chory uzyska odpowiednio $>8,7 \mathrm{i}>7,5 \mathrm{pkt}$, zgodnie z punktacją przyporządkowaną poszczególnym 


\section{SKIN LESIONS}

Skin lesions in DM can be divided into pathognomonic, highly characteristic, typical, more common in JDM, and rare [3]. Pathognomonic lesions in DM include: violaceous papules above the metacarpophalangeal and interphalangeal joints on hands (called Gottron papules, although nowadays, due to Gottron's sympathy with the Nazis, the use of his name is rather abandoned). Skin lesions highly characteristic of DM include: purplish erythema of the eyelids and swelling around eye sockets (the so-called heliotrope symptom). Other lesions typical of DM include purple reddening on dorsal surfaces of the hands, elbows, knees and ankles (Gottron's symptom), V-neck erythema and erythema of the neck and shoulders (scarf symptom), hyperkeratosis, exfoliation and cracks in the epidermis of hands, telangiectasia in the area of nail shafts, facial "malar rash" erythema and thickening and deformation of the cuticle $[1,3]$. Skin lesions are often accompanied by itch (affecting up to $80 \%$ of patients) and excessive sensitivity to ultraviolet radiation. Pruritus is an important symptom that differentiates skin eruptions in DM from lesions observed in lupus erythematosus $[4,5]$. Lesions more commonly seen in JDM are skin calcifications, especially at pressure points. Rare skin lesions in DM include non-scarring alopecia, bullous eruptions, leukocytoclastic vasculitis, livedo reticularis, and erythroderma [3]. The so-called Wong-type DM, imitating pityriasis rubra, is reported casuistically [6, 7].

\section{MUSCULAR AILMENTS}

Patients with DM usually complain of pain and reduced strength of proximal muscles, hindering, for example, climbing stairs, getting up from a sitting position, or raising arms. In extreme cases, difficulties in walking can lead to complete immobility. Muscles of the larynx, neck, intercostal muscles (respiratory function) and heart muscles may also be affected. In some cases, muscular symptoms may be weakly expressed (HDM) or absent (CADM) [1].

\section{OTHER SYMPTOMS}

The most common extra-cutaneous and extra-muscular symptoms of DM include: cardiac abnormalities, symptoms of interstitial lung disease (ILD), and presence of cancer. Cardiac disorders include: arrhythmias, congestive heart failure, myocarditis, pericarditis, angina and fibrosis. The disease is often accompanied by fever, Raynaud's phenomenon, or arthritis. Among tumors, the most commonly diagnosed in DM are breast, ovarian, lung and gastrointestinal cancer. objawom [2]. Zapalenie skórno-mięśniowe diagnozowane jest na podstawie spełnienia powyższych kryteriów i obecności co najmniej jednego kryterium dotyczącego zmian skórnych wymienionych w tabeli 1. Jeśli pacjent ma typowe dla DM zmiany skórne, biopsja mięśnia nie jest konieczna do ustalenia rozpoznania.

\section{ZMIANY SKÓRNE}

Zmiany skórne w DM można podzielić na patognomoniczne, bardzo charakterystyczne, typowe, występujące częściej w JDM oraz rzadkie [3]. Do zmian patognomonicznych dla DM należą: sinofioletowe grudki nad stawami śródręczno-międzypaliczkowymi i międzypaliczkowymi rąk (zwane grudkami Gottrona, choć obecnie z uwagi na sympatyzowanie Gottrona z nazistami raczej odchodzi się od używania jego nazwiska). Do skórnych zmian bardzo charakterystycznych dla DM zalicza się: fioletowawy rumień powiek i obrzęk wokół oczodołów (tzw. objaw heliotropu). Pozostałe zmiany typowe dla DM to: sinofioletowe rumienie na powierzchniach grzbietowych rąk, stawów łokciowych, kolanowych oraz kostek (objaw Gottrona), rumień skóry w okolicy mostka w kształcie litery V oraz rumień karku i barków (objaw szala), nadmierne rogowacenie, złuszczanie i pęknięcia naskórka dłoni, teleangiektazje w obrębie wałów paznokciowych, rumień twarzy typu malar rash oraz pogrubienie i zdeformowanie oskórka $[1,3]$. Zmianom skórnym często towarzyszy świąd (nawet u 80\% pacjentów) i nadmierna wrażliwość na promieniowanie ultrafioletowe. Świąd jest ważnym objawem różnicującym zmiany skórne w przebiegu DM od zmian w toczniu rumieniowatym [4, 5]. Zmianami częściej występującymi w JDM są zwapnienia skóry, zwłaszcza w miejscach ucisku. Rzadkie zmiany skórne w DM obejmują: łysienie niebliznowaciejące, wykwity pęcherzowe, leukocytoklastyczne zapalenie naczyń, livedo reticularis oraz erytrodermię [3]. Kazuistycznie opisywanym wariantem DM jest tzw. postać Wonga, imitująca łupież czerwony mieszkowy [6, 7].

\section{DOLEGLIWOŚCI MIĘŚNIOWE}

Chorzy z DM zazwyczaj zgłaszają bóle i osłabienie siły mięśni proksymalnych utrudniające m.in. wchodzenie po schodach, wstawanie z pozycji siedzącej czy unoszenie ramion. Trudności w poruszaniu się w skrajnych przypadkach mogą prowadzić do całkowitego unieruchomienia. Może także dojść do zajęcia mięśni krtani, szyi, międzyżebrowych (funkcjonalnie oddechowych) i serca. W niektórych przypadkach objawy mięśniowe mogą być słabo wyrażone (HDM) lub też nie występować (CADM) [1]. 


\section{ADDITIONAL INVESTIGATIONS}

As a result of muscle damage in the course of DM, an increase in serum creatine kinase and/or aldolase activity is observed, but also an increase in alanine aminotranferase and asparagine aminotranferase, and lactic acid dehydrogenase (LDH). Patients may also have elevated markers of inflammation (elevated C-reactive protein, elevated ESR) and elevated serum myoglobin levels.

In patients with suspected DM, it is advisable to perform an electromyographic examination (EMG). EMG shows features of the so-called myogenic record, indicative of primary damage to muscle cells. EMG testing may also be helpful in differentiating the symptoms of muscle DM from steroid myopathy. A valuable supplement to the diagnosis of muscle involvement in DM is also the nuclear magnetic resonance (NMR), in which it is possible to visualize inflamed muscles. Nuclear magnetic resonance is also helpful in selecting the muscle to biopsy. Due to easy availability, ultrasound can also be performed to assess muscle involvement.

Muscle biopsy remains conclusive in doubtful cases. In a typical course of DM, with classic skin lesions and typical abnormalities in laboratory investigations and diagnostic images, the examination is usually not performed. Biopsy should be performed on muscles that are mildly or moderately inflamed. In the case of muscles with a high level of inflammation, degenerative processes and necrosis may be so advanced that reliable assessment and differentiation with other inflammatory myopathies may be significantly impeded [8].

\section{AUTO-ANTIBODIES IN DERMATOMYOSITIS}

The autoantibodies present in patients with inflammatory myopathies can be divided into myositis-specific autoantibodies (MSAs) and myositis-associated autoantibodies (MAAs). The former are highly specific for inflammatory myopathies, while the latter are less specific and may also occur in other systemic connective tissue diseases [1]. Until recently, autoantibodies were thought to be present in less than half of patients with DM. The use of modern, more sensitive diagnostic methods and the discovery of a number of new autoantibodies indicate that autoantibodies may be present in up to $80 \%$ of patients. It is also increasingly emphasized that individual types of autoantibodies allow for the differentiation of DM variants and may even have prognostic significance.

The MSAs group currently includes antibodies directed against tRNA synthetases (aminoacyl-tRNA synthetases, anti-ARS), including anti-Jo-1, anti-PL-7, anti-PL-12, anti-EJ, anti-OJ, anti-KS, anti-Ha and anti-Zo antibodies, as well as anti-MDA5 (against type 5 protein associated with melanoma - also referred to

\section{POZOSTAŁE OBJAWY}

Do najczęstszych pozaskórnych i pozamięśniowych objawów DM należą: zaburzenia kardiologiczne, objawy śródmiąższowej choroby płuc (zwłóknienia płuc, interstitial lung disease - ILD) oraz obecność nowotworu. Zaburzenia kardiologiczne obejmują: zaburzenia rytmu serca, zastoinową niewydolność krążenia, zapalenie mięśnia sercowego, zapalenie osierdzia, dławicę piersiową i zwłóknienie. Chorobie często towarzyszy gorączka, objaw Raynauda lub zapalenie stawów. Spośród nowotworów w przebiegu DM najczęściej rozpoznawane są rak sutka, jajnika, płuc oraz przewodu pokarmowego.

\section{BADANIA DODATKOWE}

W wyniku uszkodzenia mięśni w przebiegu DM obserwuje się przede wszystkim wzrost aktywności kinazy kreatynowej i/lub aldolazy w surowicy, a także wzrost aktywności aminotransferazy alaninowej i asparaginowej oraz dehydrogenazy kwasu mlekowego (LDH). Pacjenci mogą mieć również podwyższone wykładniki stanu zapalnego (podwyższone stężenie białka C-reaktywnego, przyspieszone OB) oraz zwiększone stężenie mioglobiny w surowicy.

U chorych z podejrzeniem DM wskazane jest wykonanie badania elektromiograficznego (EMG), w którym stwierdza się cechy tzw. zapisu miogennego, świadczącego o pierwotnym uszkodzeniu komórek mięśniowych. Badanie EMG może być także pomocne $\mathrm{w}$ różnicowaniu objawów mięśniowych DM od miopatii posteroidowej. Cennym uzupełnieniem diagnostyki zajęcia mięśni w DM jest badanie z wykorzystaniem magnetycznego rezonansu jądrowego (nuclear magnetic resonance - NMR), w którym możliwe jest uwidocznienie zmienionych zapalnie mięśni. Badanie NMR jest także pomocne w wyborze mięśnia, z którego należy pobrać wycinek. W związku z łatwą dostępnością do oceny zajęcia mięśni można wykorzystać badanie ultrasonograficzne.

Biopsja mięśnia nadal jest badaniem rozstrzygającym w przypadkach wątpliwych. W DM o typowym przebiegu, z klasycznymi zmianami skórnymi i typowymi odchyleniami w badaniach laboratoryjnych i obrazowych zazwyczaj się jej nie wykonuje. Biopsję należy wykonać z mięśni, które są objęte procesem zapalnym o niewielkim lub umiarkowanym nasileniu. W przypadku mięśni o dużym nasileniu stanu zapalnego procesy degeneracyjne i martwica mogą być na tyle zaawansowane, że miarodajna ocena i różnicowanie $\mathrm{z}$ innymi miopatiami zapalnymi mogą być znacząco utrudnione [8].

\section{AUTOPRZECIWCIAŁA W ZAPALENIU SKÓRNO- -MIĘŚNIOWYM}

Autoprzeciwciała występujące $\mathrm{u}$ chorych na miopatie zapalne można podzielić na autoprzeciwciała swoiste dla 
as anti-CADM140 antibodies), anti-Mi-2 (anti-nuclear helicase), anti -SRP (against signal recognition particle, SRP), anti-TIF1 (against autoantigens p155/p140, transcriptional intermediary factor 1), anti-NXP2 (against nuclear matrix protein 2, antinuclear matrix protein 2, anti-NXP-2) and anti-SAE (against the SUMO-1 activating enzyme) [9].

Among anti-ARS antibodies, anti-Jo-1 antibodies are the most common, occurring in approximately $15-30 \%$ of patients with DM or polymyositis. The detection rate of other anti-ARS is estimated at less than 5\% [10]. Almost $90 \%$ of patients with anti-ARS develop ILD; in addition, it may be accompanied by arthritis and Raynaud's phenomenon, and the socalled "mechanic's hand" (hyperkeratosis, peeling and cracks in the epidermis of palmar and lateral surfaces of fingers). The detection of anti-ARS antibodies usually indicates a chronic course of the disease and a relatively good response to glucocorticosteroid (GCS) therapy [11].

In adults, development of ILD may also be associated with the presence of anti-MDA5 antibodies (also referred to as anti-CADM-140 antibodies), which are more common in the form with no muscle involvement - CADM [12]. In this group of patients, characteristic skin lesions were observed in the form of aseptic ulcers and/or painful lumps located mainly above hand joints [13]. ILD in patients with anti-MDA5 antibodies is often severe, rapidly progressing, and showing poor response to systemic GCS therapy and immunosuppressive therapy, with mortality up to 50\% [14-16]. The presence of anti-MDA5 antibodies is also associated with ulceration of the oral mucosa [13].

Anti-Mi2 antibodies are present in about $10-30 \%$ of DM patients [17]. Their presence is associated with skin lesions typical of DM, such as: Gottron's symptom and/or Gottron's papules, heliotropic erythema, nail labial erythema and hyperplasia, erythematous changes in the nape, upper back and arms (scarf symptom) and V-neck erythema. The presence of anti-Mi-2 antibodies is associated with particularly increased photosensitivity [1]. Patients with anti-Mi-2 antibodies tend to have less severe muscular symptoms, less frequent pulmonary involvement and arthritis, and generally respond well to glucocorticosteroids. Cancer is rarely found in these cases [17].

Anti-SRP antibodies show quite high specificity among patients with polymyositis and are an indicator of a poor prognosis, heralding a severe course of the disease with heart involvement and frequent exacerbations $[18,19]$. Anti-SRP antibodies are rare in people with classic DM. In the study by Hengstman et al. published in 2006, out of 23 patients with autoantibodies against SRP, only 3 were diagnosed zapalenia mięśni (myositis-specific autoantibodies - MSAs) i autoprzeciwciała towarzyszące zapaleniu mięśni (myositis-associated autoantibodies - MAAs). Pierwsze są wysoce specyficzne dla schorzeń z grupy miopatii zapalnych, drugie natomiast cechują się mniejszą swoistością i mogą również występować w przebiegu innych układowych chorób tkanki łącznej [1]. Do niedawna uważano, że autoprzeciwciała występują u mniej niż połowy chorych z DM. Zastosowanie nowoczesnych, bardziej czułych metod diagnostycznych oraz odkrycie wielu nowych autoprzeciwciał wskazuje, że autoprzeciwciała mogą występować nawet u $80 \%$ pacjentów. Coraz częściej podkreśla się także, że poszczególne typy autoprzeciwciał pozwalają na różnicowanie odmian DM, a nawet mogą mieć znaczenie rokownicze.

Do grupy MSAs zalicza się obecnie przeciwciała skierowane przeciw syntetazom tRNA (aminoacyl-tRNA synthetases - anty-ARS), w tym przeciwciała anty-Jo-1, anty-PL-7, anty-PL-12, anty-EJ, anty-OJ, anty-KS, anty-Ha i anty-Zo, a także przeciwciała anty-MDA5 (przeciw białku typu 5 związanemu z rozwojem czerniaka - określane także jako przeciwciała anty-CADM140), anty-Mi-2 (przeciw jądrowej helikazie), anty-SRP (przeciw cząsteczce rozpoznającej sygnał; signal recognition particle - SRP), anty-TIF1 (przeciw autoantygenom p155/p140, transcriptional intermediary factor 1), anty-NXP2 (przeciw białku macierzy jądrowej 2, antinuclear matrix protein 2 - anti-NXP-2) oraz anty-SAE (przeciw enzymowi aktywującemu SUMO-1, SUMO-1 activating enzyme) [9].

Spośród przeciwciał anty-ARS najczęściej stwierdza się przeciwciała anty-Jo-1, występujące u około 15-30\% chorych z DM lub zapaleniem wielomięśniowym. Częstość wykrywania pozostałych anty-ARS szacuje się na mniej niż 5\% [10]. U niemal 90\% chorych z obecnością anty-ARS rozwija się ILD. Ponadto chorobie może towarzyszyć zapalenie stawów i objaw Raynauda, a wśród zmian skórnych nierzadko obserwuje się tzw. objaw ręki mechanika (hiperkeratoza, złuszczanie i pęknięcia naskórka opuszek oraz bocznych powierzchni palców rąk). Wykrycie przeciwciał anty-ARS zwykle wskazuje na przewlekły przebieg choroby i względnie dobrą reakcję na glikokortykosteroidy (GKS) [11].

U osób dorosłych wystąpienie ILD może się wiązać z występowaniem przeciwciał anty-MDA5 (określanych także jako przeciwciała anty-CADM-140), które częściej występują w postaci bez zajęcia mięśni - CADM [12]. W tej grupie chorych obserwowano charakterystyczne zmiany skórne w postaci aseptycznych owrzodzeń i/lub bolesnych grudek, zlokalizowanych głównie nad stawami rąk [13]. ILD u chorych z przeciwciałami anty-MDA5 ma często ciężki przebieg, szybko postępuje i wykazuje słabą reakcję na ogólną terapię GKS i leczenie immunosupresyjne, a śmiertelność sięga nawet 50\% [14-16]. Obecność przeciwciał anty-MDA5 wiąże się także z owrzodzeniami błony śluzowej jamy ustnej [13]. 
with DM, and the remaining were PM [20]. The presence of anti-SRP antibodies is associated with a significant reduction of muscle strength leading to significant disability, dysphagia and high levels of serum phosphocreatine kinase (CPK) levels (CPK $>10,000 \mathrm{U} / \mathrm{l})$. ILD, arthritis and Raynaud's phenomenon are less commonly diagnosed [19]. Patients with anti-SRP antibodies often respond poorly to treatment with glucocorticosteroids. Also in the case of JDM, the presence of anti-SRP antibodies is associated with a less favorable prognosis [21].

Autoantibodies directed against the $155 \mathrm{kDa}$ and $140 \mathrm{kDa}$ protein doublet (p155/140 autoantigen), also known as anti-TIF1 antibodies, discovered in the early 2000s, are associated with an increased risk of cancer, especially in patients who develop DM after 40 years of age [19]. The described antibodies are $89 \%$ specific and $78 \%$ sensitive for cancer [22]. Moreover, dysphagia is common in people with anti-TIF1 antibodies [23]. Due to the possibility of coexistence of DM with malignant tumors, diagnosis aimed at exclusion of presence of cancer should be performed in all patients diagnosed with DM. At least the following examinations are recommended: X-ray or computed tomography of lungs, ultrasound examination of the abdominal cavity and pelvis (if necessary, computed tomography of the abdominal cavity and/or pelvis), gastro- and colonoscopy, and in women additionally mammography and gynecological examination. It may also be helpful to perform other imaging tests (ultrasound of the thyroid gland, head and neck tomography) and the so-called tumor markers (including Ca125, Ca15.3, Ca19.9, CEA, a-fetoprotein, PSA, SCC antigen, HE4).

Other antibodies that may also indicate cancer are those directed against the NXP2 protein [24]. These antibodies are also detected in people with a severe course of DM, especially in the case of JDM, where they are often associated with arthritis, muscle contractures and subcutaneous calcinosis [1, 19].

Anti-SAE antibodies directed against the enzyme activating the SUMO-1 heterodimer are associated with the presence of severe skin lesions and relatively poorly expressed symptoms of myositis. In patients with anti-SAE antibodies, dysphagia resulting from the involvement of the esophageal muscles is often found, while ILD is rarely observed [25].

Antibodies belonging to the MAAs group are of less diagnostic importance for DM because they are also present in other diseases of connective tissue. Anti-PM-Scl, anti-Ku, anti-Ro, anti-La, anti-U1RNP and anti-U3RNP antibodies were found in DM. These antibodies are often detected in the course of the socalled overlap syndromes in which patients have
Przeciwciała anty-Mi2 występują u około $10-30 \%$ chorych z DM [17]. Ich obecność jest zwiazana z typowymi dla DM zmianami skórnymi, takimi jak objaw i/lub grudki Gottrona, rumień heliotropowy, rumień i rozrost obrąbka paznokcia, zmiany rumieniowe dotyczące karku, górnej części pleców i ramion (objaw szala) oraz skóry w okolicy mostka (rumień w kształcie litery V). Występowanie przeciwciał anty-Mi-2 łączy się ze szczególnie nasiloną fotowrażliwością [1]. Pacjenci, u których stwierdzane są przeciwciała anty-Mi-2, mają zwykle mniej nasilone objawy mięśniowe, rzadziej występuje u nich zajęcie płuc oraz zapalenie stawów i zazwyczaj dobrze odpowiadają na leczenie GKS. Rzadko w tych przypadkach stwierdza się występowanie nowotworu [17].

Przeciwciała anty-SRP wykazują dość dużą swoistość u pacjentów z zapaleniem wielomięśniowym i są wskaźnikiem złego rokowania, zwiastując ciężki przebieg choroby z zajęciem serca i częstymi zaostrzeniami $[18,19]$. U osób z klasycznym DM przeciwciała anty-SRP występują rzadko. W badaniu Hengstmana i wsp. opublikowanym w 2006 roku, spośród 23 pacjentów z autoprzeciwciałami przeciwko SRP jedynie u 3 rozpoznano DM, a u pozostałych PM [20]. Obecność przeciwciał anty-SRP wiąże się z dużym osłabieniem siły mięśniowej, które prowadzi do istotnej niepełnosprawności, dysfagii oraz wysokich stężeń kinazy fosfokreatynowej (CPK) w surowicy (CPK > $10000 \mathrm{U} / 1)$. Rzadziej natomiast stwierdza się ILD, zapalenie stawów i objaw Raynauda [19]. Chorzy, u których obecne są przeciwciała anty-SRP, nierzadko słabo reagują na GKS. Również w przypadku JDM obecność przeciwciał anty-SRP wiąże się z gorszym rokowaniem [21].

Odkryte na początku XXI wieku autoprzeciwciała skierowane przeciwko dubletowi białek o masie $155 \mathrm{kDa}$ i 140 kDa (autoantygen p155/140), określane także mianem przeciwciał anty-TIF1, wiążą się ze zwiększonym ryzykiem występowania nowotworów, zwłaszcza u pacjentów, u których DM pojawiło się po 40. roku życia [19]. Opisywane przeciwciała cechuje 89-procentowa swoistość i 78-procentowa czułość dla stwierdzenia nowotworu [22]. Ponadto u osób z przeciwciałami anty-TIF1 często występuje dysfagia [23]. Z uwagi na możliwość współistnienia DM z nowotworami złośliwymi u wszystkich chorych z rozpoznanym DM należy przeprowadzić diagnostykę w celu wykluczenia nowotworu. Zaleca się wykonanie co najmniej następujących badań: rentgenogram lub tomografia komputerowa płuc, badanie ultrasonograficzne jamy brzusznej i miednicy (w razie potrzeby tomografia komputerowa jamy brzusznej i/lub miednicy), gastro- i kolonoskopia, a u kobiet dodatkowo mammografia i badanie ginekologiczne. Pomocne może być także wykonanie innych badań obrazowych (USG tarczycy, tomografia głowy i szyi) oraz oznaczenie tzw. markerów nowotworowych (m.in. Ca125, Ca15.3, Ca19.9, CEA, a-fetoproteina, PSA, antygen SCC, HE4). 
symptoms of other connective tissue diseases in addition to those typical of DM.

\section{RELATIONSHIP BETWEEN DERMATOMYOSITIS AND CANCER}

Of all inflammatory myopathies, DM has the strongest association with malignant tumors. The pathogenesis of DM formation in the course of cancer is not fully understood. However, the influence of antigenic stimulation of the immune system by cancer cells and the humoral and cellular reactivity altered by the neoplastic process is emphasized. Dermatomyositis may precede the diagnosis of tumor, be diagnosed at the same time, or after its detection [1]. In some cases, symptoms of DM may precede the detection of cancer by up to 5 years or more [26]. However, there is a different course of the disease depending on the age of onset. In children, tumors in the course of DM are practically absent. On the other hand, in adults, DM may be associated with coexisting malignant tumor in about $10-20 \%$ of cases, although the risk increases with age. The diagnosis of paraneoplastic syndrome usually concerns patients over 50 years of age, in whom symptoms of DM persist for at least 12 months, with coexisting dysphagia, anemia and skin necrotic changes [27]. In most cases, a reduction in severity of both skin lesions and muscle symptoms of DM is observed after successful cancer therapy. As mentioned above, DM as a paraneoplastic syndrome is most often associated with anti-TIF-1 antibodies and, to a lesser extent, with anti-NPX2. In turn, the occurrence of ILD, arthralgia/arthritis, secondary Raynaud's phenomenon and the presence of anti-Jo-1 antibodies were correlated with a lower risk of coexisting cancer [28].

\section{TREATMENT}

People with DM often require an interdisciplinary approach and are treated by specialists in various fields of medicine, especially by dermatologists, rheumatologists, pediatricians, and neurologists. Participation of physiotherapists is also very important. Because of the low incidence of the disease and the related fact that well-designed clinical trials are scarce, principles of DM therapy are largely based on opinions and experience of experts. Randomized clinical trials and meta-analyzes are few. Moreover, the response to treatment has so far been assessed using various tools, depending on the type of lesions: muscle, skin, pulmonary, cardiological, or skin calcifications, which made it difficult to directly compare results of studies presented by different authors. Only in recent years,
Innymi przeciwciałami, które mogą wskazywać na nowotwór, są przeciwciała skierowane przeciwko białku NXP2 [24]. Wykrywa się je także u osób z ciężkim przebiegiem DM, zwłaszcza w JDM, w przypadku którego często łączą się z zapaleniem stawów, przykurczami mięśni i wapnicą podskórną [1,19].

Skierowane przeciwko enzymowi aktywującemu heterodimer SUMO-1 przeciwciała anty-SAE są związane z obecnością nasilonych zmian skórnych i relatywnie słabo wyrażonymi objawami zapalenia mięśni. U chorych z przeciwciałami anty-SAE często stwierdza się dysfagię wynikającą z zajęcia mięśni przełyku, rzadko natomiast ILD [25].

Przeciwciała zaliczane do grupy MAAs mają mniejsze znaczenie diagnostyczne dla DM, ponieważ występują także w innych chorobach tkanki łącznej. W DM stwierdzano obecność przeciwciał anty-PM-Scl, anty-Ku, anty-Ro, anty-La, anty-U1RNP i anty-U3RNP. Przeciwciała te często są wykrywane w przebiegu tzw. zespołów nakładania, w których pacjenci poza objawami typowymi dla DM mają także objawy innych chorób tkanki łącznej.

\section{ZWIAZZEK ZAPALENIA SKÓRNO-MIĘŚNIOWEGO Z NOWOTWORAMI}

Spośród wszystkich miopatii zapalnych DM cechuje się najsilniejszym związkiem z nowotworami złośliwymi. Patogeneza powstawania DM w przebiegu chorób nowotworowych nie jest dokładnie poznana. Podkreśla się jednak wpływ stymulacji antygenowej układu immunologicznego przez komórki nowotworowe i zmienioną przez proces nowotworowy odczynowość humoralną i komórkową. Zapalenie skórno-mięśniowe może poprzedzać rozpoznanie nowotworu, zostać rozpoznane w tym samym czasie co choroba nowotworowa lub już po jej wykryciu [1]. W niektórych przypadkach objawy DM poprzedzają wykrycie choroby nowotworowej nawet o 5 lat lub dłużej [26]. Zwraca jednak uwagę odmienny przebieg choroby w zależności od wieku zachorowania. U dzieci nowotwory w przebiegu DM praktycznie nie występują, natomiast $\mathrm{u}$ dorosłych DM może być związane ze współistniejącym nowotworem złośliwym w około $10-20 \%$ przypadków, a ryzyko to wzrasta z wiekiem. Rozpoznanie zespołu paraneoplastycznego dotyczy zwykle chorych powyżej 50. roku życia, u których objawy DM utrzymują się co najmniej 12 miesięcy, ze współistniejącą dysfagią, anemią oraz zmianami martwiczymi skóry [27]. W większości przypadków po skutecznej terapii nowotworu obserwuje się zmniejszenie nasilenia DM, zarówno zmian skórnych, jak i objawów mięśniowych. Jak wspomniano powyżej, DM jako zespół paraneoplastyczny najczęściej wiąże się z występowaniem przeciwciał anty-TIF-1 oraz w mniejszym stopniu anty-NPX2. Wystąpienie ILD, artralgii lub zapalenia stawów, wtórnego objawu Raynauda oraz obecność przeciwciał anty-Jo-1 były skorelowane z niższym ryzykiem współistnienia nowotworu [28]. 
the ACR-EULAR has defined criteria for small, medium and significant improvement in children and adults with DM $[29,30]$. Recommendations were also made to establish uniform therapeutic standards. In 2010-2012, the Childhood Arthritis and Rheumatology Research Alliance (CARRA) consensus was established on the treatment of moderate and severe JDM. In 2017, CARRA recommendations were published, and in 2018 the Single Hub and Access Point for Pediatric Rheumatology in Europe (SHARE), containing a treatment plan for children with DM as a spectrum of various severity of symptoms, including JDM therapy with dominant or persistent skin lesions [31-36]. According to the above recommendations, glucocorticosteroids administered both orally and by intravenous infusions are the main medications in the treatment of moderate to severe JDM. Methotrexate (MTX) is also recommended [33]. In severe cases, in absence of improvement after the basic treatment, intravenous immunoglobulins (IVIg), mycophenolate mofetil (MMF) or cyclosporin should be considered [33]. According to CARRA, such treatment is often required in patients showing improvement in muscles, but with persistent skin lesions that are resistant to treatment [36]. However, in the case of dominance of dermatological symptoms, monotherapy with hydroxychloroquine or chloroquine is indicated. In the case of resistance of skin lesions, it is possible to add MTX or MTX and prednisone [34], however, it should be remembered that chloroquine and hydroxychloroquine may reduce the effectiveness of MTX, possibly by influencing its bioavailability.

In DM, muscle and skin lesions often show differences in response to treatment, with skin lesions appearing to be more resistant to treatment. In patients with the amiopathic form of DM without lung involvement, strict photoprotection, local treatment (GCS or calcineurin inhibitors), antipruritic drugs and antimalarial drugs should be recommended. However, effects of hydroxychloroquine treatment of cutaneous DM manifestation are worse compared to the results in lupus erythematosus, and patients often require administration of other immunosuppressants (MTX, MMF, azathioprine) or IVIg. It may also be advantageous to use dapsone, calcineurin inhibitors, inhibitors of Janus kinases or leflunomide.

In adult patients with classic DM, as in children, glucocorticosteroid therapy, used at high doses (prednisone orally at a dose of $0.75-1.0 \mathrm{mg} / \mathrm{kg} \mathrm{bw} /$ day or pulse therapy with high doses of methylprednisolone) in the induction phase, may be considered as the treatment of choice intravenously. Induction treatment and slow GC dose reduction within 2448 months allows for remission in over $70 \%$ of pa-

\section{LECZENIE}

Osoby chore na DM wymagają często interdyscyplinarnego podejścia i są leczone przez specjalistów z różnych dziedzin medycyny, szczególnie przez dermatologów, reumatologów, pediatrów i neurologów. Bardzo istotny jest też udział fizjoterapeutów. Ze względu na niską częstość występowania choroby i związaną z tym niewielką liczbę dobrze zaplanowanych badań klinicznych zasady terapii DM oparte są w dużej mierze na opiniach i doświadczeniu ekspertów. Badania kliniczne $\mathrm{z}$ randomizacją i metaanalizy są nieliczne. Ponadto dotychczas odpowiedź na leczenie oceniano za pomocą różnych narzędzi, w zależności od rodzaju zmian chorobowych: mięśniowych, skórnych, płucnych, kardiologicznych lub zwapnień skóry, co utrudniało bezpośrednio porównanie wyników badań różnych autorów. Dopiero w ostatnich latach w ramach ACR-EULAR zdefiniowano kryteria niewielkiej, średniej i znacznej poprawy u dzieci i dorosłych z DM $[29,30]$. Podjęto się również tworzenia rekomendacji w celu ustalenia jednolitych standardów terapeutycznych. W latach 2010-2012 powstawał konsensus Childhood Arthritis and Rheumatology Research Alliance (CARRA) odnoszący się do leczenia umiarkowanego i ciężkiego JDM. W 2017 roku ukazały się zalecenia CARRA, a w 2018 roku Single Hub and Access Point for Pediatric Rheumatology in Europe (SHARE), zawierające plan leczenia dzieci z DM o różnym nasileniu objawów, w tym terapii JDM z dominującymi lub uporczywymi zmianami skórnymi [31-36]. Zgodnie z powyższymi zaleceniami w leczeniu JDM o umiarkowanym lub ciężkim nasileniu podstawowymi lekami są GKS podawane zarówno doustnie, jak i we wlewach dożylnych. Równolegle zaleca się metotreksat (MTX) [33]. W ciężkich przypadkach, przy braku poprawy po leczeniu podstawowym, należy rozważyć zastosowanie dożylnych immunoglobulin (intravenous immunoglobulins - IVIg), mykofenolanu mofetylu (MMF) lub cyklosporyny [33]. Według CARRA postępowanie takie często jest konieczne $\mathrm{u}$ chorych wykazujących poprawę $\mathrm{w}$ zakresie mięśni, ale z uporczywymi, opornymi na leczenie zmianami skórnymi [36]. Przy dominacji objawów dermatologicznych wskazana jest monoterapia hydroksychlorochiną lub chlorochiną. W razie oporności zmian skórnych możliwe jest dołączenie MTX lub MTX i prednizonu [34], jednak należy pamiętać, że chlorochina i hydroksychlorochina mogą zmniejszać skuteczność MTX, prawdopodobnie poprzez wpływ na jego biodostępność.

W DM zmiany mięśniowe i skórne często wykazują różnice w odpowiedzi na leczenie, przy czym zmiany skórne wydają się bardziej oporne niż mięśniowe. Chorym z postacią amiopatyczną DM bez zajęcia płuc należy zalecić przede wszystkim ścisłą fotoprotekcję, leczenie miejscowe (GKS lub inhibitory kalcyneuryny), leki przeciwświądowe i przeciwmalaryczne. Efekty leczenia hydroksychlorochiną skórnych objawów DM są jednak 
tients [6]. Drugs recommended for the treatment of DM are discussed below.

\section{Systemic glucocorticosteroids}

Considering information provided above, systemic glucocorticosteroid therapy remains the treatment of choice in DM. Classically, prednisone is recommended, at the initial dose of $0.75-1 \mathrm{mg} / \mathrm{kg}$ b.w./ day. In more severe cases, especially with a more intense muscle involvement, administration of 3 to 5 intravenous pulses of methylprednisolone, 1000$1500 \mathrm{mg}$ each, it is recommended, and continuation of the therapy with the maintenance dose of oral GCs, gradually lowered as the clinical symptoms disappear $[1,6]$. If no improvement is observed in the period of about 12 weeks of GC monotherapy, it is advisable to add an immunosuppressive drug [6]. It seems that early administration of immunosuppressive treatment improves the results of therapy and allows for a reduction of the cumulative dose of glucocorticosteroids. That is why some experts prefer to switch to immunosuppressive drugs earlier. Combined immunosuppressive therapy is also recommended at the beginning of therapy in cases of worse prognosis, e.g., in the presence of certain types of autoantibodies (e.g., anti-SRP). In addition, combined treatment (GCs and immunosuppressive drug) is also indicated in the case of failure to achieve a permanent remission, frequent relapses of the disease and severe side effects of GCs. The factor significantly limiting the use of glucocorticoids is the high risk of side effects. Medical consequences in patients with DM are often not caused by disease complications, but by side effects of GCs, which include, among others, sterile bone necrosis, steroid myopathy and vertebral osteoporotic fractures $[1,6]$.

The duration of the use of glucocorticoids in DM has not been precisely defined, but most researchers believe that the therapy should last at least 12-24 months. Premature discontinuation of the treatment or too rapid reduction of the dose of glucocorticosteroids is associated with a significant risk of relapse. The duration of therapy should depend primarily on the dynamics of disappearance of particular disease symptoms and CPK activity [37]. Skin lesions disappear much slower than muscle symptoms, therefore, at their low intensity, as well as in the absence of muscle weakness, maintenance of high doses of GCs is not recommended. In such cases, it is recommended to add an immunosuppressive drug, as well as to intensify local therapy [1]. Among the factors influencing a worse response to GC therapy are: late initiation of treatment, older age of patients, involvement of internal organs, coexistence of cancer, and presence of anti-synthetase autoantibodies and anti-SRP autoantibodies [37]. gorsze w porównaniu efektami leczenia w toczniu rumieniowatym, nierzadko konieczne jest wdrożenie innych leków immunosupresyjnych (MTX, MMF, azatiopryny) lub IVIg. Korzystne może być zastosowanie dapsonu, inhibitorów kalcyneuryny, inhibitorów kinaz janusowych lub leflunomidu.

U dorosłych pacjentów z klasycznym DM, podobnie jak u dzieci, można rozważyć jako leczenie z wyboru glikokortykosteroidoterapię stosowaną $\mathrm{w}$ fazie indukcji w wysokich dawkach (prednizon doustnie w dawce 0,75-1,0 mg/kg m.c./dobę lub pulsoterapię wysokimi dawkami metyloprednizolonu dożylnie). Leczenie indukcyjne i powolne obniżanie dawki GKS w czasie 24-48 miesięcy pozwala na uzyskanie remisji u ponad $70 \%$ chorych [6]. Poniżej omówiono leki rekomendowane w leczeniu DM.

\section{Glikokortykosteroidy ogólne}

Biorąc pod uwagę informacje podane powyżej, glikokortykosteroidoterapia ogólna jest leczeniem z wyboru w DM. Klasycznie zaleca się stosowanie prednizonu w dawce początkowej 0,75-1 mg/kg m.c./dobę. W cięższych przypadkach, zwłaszcza przy nasilonym zajęciu mięśni, rekomenduje się podanie od 3 do 5 pulsów dożylnych metyloprednizolonu po 10001500 mg każdy i kontynuowanie terapii dawką podtrzymującą doustnych GKS, stopniowo obniżaną wraz z ustępowaniem objawów klinicznych $[1,6]$. W przypadku braku poprawy w okresie około 12 tygodni monoterapii GKS wskazane jest dołączenie leku immunosupresyjnego [6]. Wydaje się, że wczesne zastosowanie leczenia immunosupresyjnego poprawia wyniki oraz pozwala na zmniejszenie kumulacyjnej dawki GKS. Z tego powodu część ekspertów preferuje wcześniejsze włączenie leków immunosupresyjnych. Skojarzone leczenie immunosupresyjne jest też zalecane na początku terapii w przypadkach o gorszym rokowaniu, np. w razie stwierdzenia niektórych typów autoprzeciwciał (np. anty-SRP). Ponadto leczenie skojarzone (GKS i lek immunosupresyjny) jest zalecane w przypadku nieuzyskania trwałej remisji, częstych nawrotów choroby oraz nasilonych objawów niepożądanych GKS. Czynnikiem istotnie ograniczającym stosowanie GKS jest duże ryzyko wystąpienia działań niepożądanych, przy czym konsekwencje medyczne $\mathrm{u}$ chorych $\mathrm{z}$ DM nierzadko nie są spowodowane powikłaniami choroby, ale działaniami niepożądanymi GKS, do których należą m.in. jałowa martwica kości, miopatia posteroidowa i złamania osteoporotyczne kręgów [1, 6].

Długość czasu stosowania GKS w DM nie została dokładnie określona, ale większość badaczy uważa, że terapia powinna trwać co najmniej 12-24 miesiące. Zbyt wczesne odstawienie leczenia lub zbyt szybkie obniżenie dawki GKS wiąże się z istotnym ryzykiem nawrotu choroby. Czas trwania terapii zależy przede 


\section{Immunosuppressive drugs}

First of all, immunosuppressive drugs help to limit the total dose of systemic glucocorticosteroids. The use of immunosuppressive drugs is largely based on observations of small groups of patients and on expert experience. The most commonly prescribed drugs in this group include azathioprine (AZA), MTX, cyclosporine, MMF, and cyclophosphamide (CYC).

\section{Azathioprine}

The drug is administered orally, usually at the dose of $1-3 \mathrm{mg} / \mathrm{kg} \mathrm{b.w./day.} \mathrm{The} \mathrm{percentage} \mathrm{of}$ a good response to AZA is high, especially with regard to improvement of muscle strength. Therefore, for many clinicians it is the preferred immunosuppressive drug in DM [38]. It should be noted, however, that the response to AZA is relatively slow, and the full effect of the drug is only achieved after several weeks or even months. The most commonly observed side effects of AZA include suppression of bone marrow function, hepatotoxicity, hypersensitivity reactions and an increased risk of developing non-melanocytic skin cancer. Before starting the treatment, it is recommended that the serum level of thiopurine methyltransferase or the genotype of this enzyme be determined. This enzyme is responsible for the proper metabolism of azathioprine, and its activity is reduced in about $10 \%$ of the population. If these investigations cannot be performed, weekly blood counts are recommended for the first 8 weeks of therapy, and then at monthly intervals.

\section{Methotrexate}

For DM therapy, MTX can be administered orally or subcutaneously at the dose of 10-25 mg/week. The drug is effective both in relation to muscle ailments and skin lesions $[39,40]$. The unquestionable advantage of MTX over AZA is the speed of response. Improvement of muscle strength and reduction of $\mathrm{CPK}$ activity usually occurs after 6-8 weeks of the treatment [1].

\section{Cyclosporine}

There are single reports of efficacy of cyclosporine in patients with inflammatory myopathies who were refractory to the combination therapy of glucocorticosteroids with other immunosuppressants, especially in children [41]. Moreover, cyclosporine is a drug that, when administered at high doses (5-7.5 mg/ $\mathrm{kg}$ b.w./day), may inhibit progression of ILD in the course of inflammatory myopathies [40, 41]. However, taking into account the relatively high frequency of side effects and lower efficacy compared to AZA wszystkim od dynamiki ustępowania poszczególnych objawów i aktywności CPK [37]. Zmiany skórne ustępują znacznie wolniej niż objawy mięśniowe, dlatego przy ich małym nasileniu, jak również przy braku osłabienia siły mięśniowej nie zaleca się utrzymywania wysokich dawek GKS. W takich przypadkach rekomendowane jest dołączenie leku immunosupresyjnego, a także intensyfikacja leczenia miejscowego [1]. Wśród czynników wpływających na gorszą odpowiedź na terapię GKS wymienia się przede wszystkim: późne rozpoczęcie leczenia, starszy wiek pacjentów, zajęcie narządów wewnętrznych, współistnienie nowotworu oraz obecność autoprzeciwciał antysyntetazowych i anty-SRP [37].

\section{Leki immunosupresyjne}

Leki immunosupresyjne przede wszystkim pozwalają ograniczyć łączną dawkę stosowanych ogólnie GKS. Wykorzystanie leków immunosupresyjnych opiera się głównie na obserwacjach niewielkich grup chorych oraz doświadczeniu eksperckim. Do najczęściej zalecanych leków z tej grupy zalicza się azatioprynę (AZA), MTX, cyklosporynę, MMF i cyklofosfamid (CYC).

\section{Azatiopryna}

Lek podawany jest doustnie, zwykle w dawce 1-3 mg/kg m.c./dobę. Odsetek dobrych odpowiedzi na AZA jest wysoki, szczególnie w zakresie poprawy siły mięśniowej, dlatego dla wielu klinicystów jest to preferowany w DM lek immunosupresyjny [38]. Należy jednak zaznaczyć, że odpowiedź na AZA jest stosunkowo wolna, a pełne działanie leku osiąga się dopiero po kilku tygodniach, a nawet miesiącach. Do najczęściej obserwowanych działań niepożądanych AZA należą: supresja funkcji szpiku kostnego, hepatotoksyczność, reakcje nadwrażliwości i zwiększone ryzyko rozwoju niemelanocytowych nowotworów skóry. Przed rozpoczęciem leczenia rekomendowane jest oznaczenie stężenia metylotransferazy tiopurynowej w surowicy lub genotypu tego enzymu. Odpowiada on za zdolność do prawidłowego metabolizowania AZA, a jego aktywność jest obniżona u około $10 \%$ populacji. W przypadku braku możliwości wykonania tych badań wskazane jest cotygodniowe oznaczanie morfologii krwi przez pierwszych 8 tygodni terapii, a następnie w odstępach miesięcznych.

\section{Metotreksat}

W terapii DM MTX może być podawany doustnie lub podskórnie w dawce 10-25 mg tygodniowo. Lek jest skuteczny zarówno w przypadku dolegliwości mięśniowych, jak i zmian skórnych [39, 40]. Niewątpliwą przewagą MTX nad AZA jest szybkość odpowiedzi. Poprawa siły mięśniowej i redukcja aktywno- 
and MTX, this drug should only be used in cases of failure of therapy with other immunosuppressants.

\section{Mofetil mycophenolate}

Based on results of studies analyzing series of cases and clinical trials in small groups of patients, MMF administered at the dose of up to $3 \mathrm{~g} /$ day caused an increase in muscle strength in nearly $90 \%$ of patients $[42,43]$. MMF can also be used as the drug of first choice in combination treatment with glucocorticosteroids in patients at increased risk of ILD. It has been shown that the drug can slow down the progress of lung lesions by reducing the expression of profibrotic cytokines [44]. Therapy with MMF may also be effective in cases of skin lesions resistant to treatment with other immunosuppressive drugs [40].

\section{Cyclophosphamide}

Despite its demonstrated efficacy, CYC is recommended only in cases of DM with severe and rapidly progressive ILD. This is due to the significant toxicity and potentially carcinogenic effect of the drug, depending on its cumulative daily dose. It is recommended to use intravenous pulses at the dose of $0.5-1 \mathrm{~g} / \mathrm{m}^{2}$ BSA or orally at the dose of $1.5-2 \mathrm{mg} /$ $\mathrm{kg}$ b.w./day [37, 40,45]. CYC is not recommended for the treatment of children and has not been included in the CARRA recommendations. However, it's efficacy is recognized in severe JDM, but the drug is rarely recommended due to potential side effects. On the other hand, SHARE, in severe states of juvenile $\mathrm{DM}$, suggests considering the administration of CYC in monthly intravenous infusions for 3-6 months, and longer if necessary [35].

\section{Antimalarial drugs}

Antimalarial preparations are a group of drugs with a complex and not fully understood mechanism of action. However, their anti-inflammatory, anti-proliferative and photoprotective properties are widely recognized. Antimalarial drugs (chloroquine, hydroxychloroquine) are used primarily in the treatment of skin lesions. However, they do not show significant efficacy in the treatment of muscle symptoms [40, 46]. In the form of CADM, antimalarial preparations are considered drugs of first choice, although they do not always bring the expected improvement [40]. They can also be recommended in cases of classic DM with treatment-resistant skin lesions as an additional drug [1]. The most common dosage of chloroquine for adults is $250 \mathrm{mg}$ twice a day for 2 weeks, followed by $250 \mathrm{mg}$ once a day, while of hydroxychloroquine it is $200-400 \mathrm{mg} /$ day. ści CPK następują zwykle już po 6-8 tygodniach od rozpoczęcia leczenia [1].

\section{Cyklosporyna}

Istnieją pojedyncze opisy skuteczności cyklosporyny u chorych z miopatiami zapalnymi, które były oporne na terapię skojarzoną GKS z innymi lekami immunosupresyjnymi, zwłaszcza u dzieci [41]. Ponadto cyklosporyna podawana w dużych dawkach (5-7,5 mg/kg m.c./ dobę) może hamować progresję ILD w przebiegu miopatii zapalnych $[40,41]$. Ze względu na stosunkowo dużą częstość występowania działań niepożądanych i mniejszą skuteczność niż AZA lub MTX lek ten powinien być stosowany dopiero w przypadkach niepowodzenia terapii innymi lekami immunosupresyjnymi.

\section{Mykofenolan mofetylu}

Jak wynika z badań analizujących serie przypadków i badań klinicznych w małych grupach pacjentów, MMF podawany w dawce do $3 \mathrm{~g} /$ dobę powodował wzrost siły mięśniowej u blisko $90 \%$ leczonych $[42,43]$. MMF może być także stosowany jako lek pierwszego wyboru w leczeniu skojarzonym z GKS $\mathrm{u}$ chorych ze zwiększonym ryzykiem rozwoju ILD. Wykazano bowiem, że może on spowalniać postęp zmian w płucach poprzez redukcję ekspresji cytokin profibrotycznych [44]. Terapia z zastosowaniem MMF może być także skuteczna w przypadkach zmian skórnych opornych na leczenie innymi lekami immunosupresyjnymi [40].

\section{Cyklofosfamid}

Pomimo wykazanej skuteczności CYC jest rekomendowany jedynie w przypadkach DM z ILD o ciężkim i szybko postępującym przebiegu. Wynika to $\mathrm{z}$ jego dużej toksyczności i potencjalnie kancerogennego działania, zależnego od skumulowanej dawki życiowej. Zaleca się terapię pulsami dożylnymi w dawce $0,5-1 \mathrm{~g} / \mathrm{m}^{2}$ p.c. lub doustnie $w$ dawce $1,5-$ $2 \mathrm{mg} / \mathrm{kg}$ m.c./dobę [37, 40, 45]. CYC nie jest zalecany do leczenia dzieci i nie został uwzględniony w rekomendacjach CARRA. Jest natomiast lekiem o uznanej skuteczności w ciężkim JDM, ale ze względu na potencjalne objawy uboczne rzadko zalecanym. Natomiast autorzy zaleceń SHARE w ciężkich stanach młodzieńczej postaci DM proponują rozważenie podania CYC w dożylnych comiesięcznych wlewach przez 3-6 miesięcy, a w razie potrzeby dłużej [35].

\section{Leki przeciwmalaryczne}

Preparaty przeciwmalaryczne stanowią grupę leków o złożonym i nie w pełni poznanym mechanizmie działania. Powszechnie uznawane jest jednak ich działanie przeciwzapalne, antyproliferacyjne, a także właściwości 


\section{Dapsone}

Data on the effectiveness of dapsone are limited. This drug can be used in resistant skin lesions after failure of other therapeutic methods [45].

\section{Janus kinase inhibitors}

Recent reports highlight the beneficial effects of Janus kinase inhibitors (tofacitinib, ruxolitinib, baricitinib) in children and adults with both newly diagnosed and refractory DM [47, 48]. A randomized phase Ila study is currently being conducted to assess the efficacy and safety of baricitinib in adult patients with IIM (EudraCT Number: 2019-003868-42).

\section{Intravenous immunoglobulins}

IVIg therapy is recommended in patients with DM if GKS, AZA, MTX therapy and other immunosuppressive drugs fail (fig. 1). Effectiveness of this form of treatment is relatively well documented. The recommended dose of IVIg is $2 \mathrm{~g} / \mathrm{kg}$ b.w. for 2-5 days once a month until remission is achieved. IVIg treatment contributes to the improvement of strength of proximal muscles and reduction of CPK activity, as well as reduction of severity of skin lesions [37]. In cases resistant to combined treatment with cyclosporine and prednisone, the addition of IVIg increased the chance of achieving complete remission [46]. Beneficial effects of IVIg have also been reported in the paraneoplastic form of DM as well as in pregnant women with DM. Clinical improvement was also observed in the treatment of ulcerations and vascular lesions resistant to prednisone and other immunosuppressive drugs. Because of the lower effectiveness in comparison to GCs, administration of IVIg as the initial form of therapy does not seem to be justified. If IVIg treatment is discontinued, recurrence of muscle weakness is observed in some patients, therefore, in order to maintain the effect of this therapy, it may be necessary to repeat infusions every 6-12 months in some patients. In Poland, the treatment of DM with IVIg is carried out mainly under the B67 drug program of the Ministry of Health "Treatment of neurological diseases with immunoglobulins", although, as the name suggests, this program is dedicated to neurologists.

IVIg treatment is relatively well tolerated with a low incidence of side effects. The most common are nausea and vomiting, asthenia, hypersensitivity reactions (rarely anaphylaxis), osmotic nephrosis, thromboembolic events and aseptic meningitis [1].

\section{Biological treatment}

Rituximab

Initially, based on individual case reports, rituximab was greatly hoped to be an effective form of fotoprotekcyjne. Leki przeciwmalaryczne (chlorochina, hydroksychlorochina) mają zastosowanie przede wszystkim w leczeniu zmian skórnych. Nie wykazują natomiast istotnej skuteczności w terapii objawów mięśniowych $[40,46]$. W postaci CADM preparaty przeciwmalaryczne uznawane są za leki pierwszego wyboru, choć nie zawsze przynoszą spodziewaną poprawę [40]. Mogą być także rekomendowane w przypadkach klasycznego DM przebiegającego z opornymi na leczenie zmianami skórnymi jako lek dodatkowy [1]. Najczęściej stosowane $\mathrm{u}$ dorosłych dawkowanie chlorochiny to $250 \mathrm{mg} 2 \mathrm{razy}$ na dobę, przez 2 tygodnie, a następnie $250 \mathrm{mg}$ raz na dobę, natomiast w przypadku hydroksychlorochiny 200-400 mg/dobę.

\section{Dapson}

Dane na temat skuteczności dapsonu są ograniczone. Lek ten może być stosowany w przypadkach opornych zmian skórnych, po niepowodzeniu innych metod terapeutycznych [45].

\section{Inhibitory kinaz janusowych}

Ostatnie doniesienia zwracają uwagę na korzystne efekty zastosowania inhibitorów kinaz janusowych (tofacytynibu, ruksolitynibu, baricytynibu) u dzieci i dorosłych zarówno z nowo rozpoznanym, jak i opornym na leczenie DM $[47,48]$. Aktualnie toczy się badanie fazy IIa z randomizacją oceniające skuteczność i bezpieczeństwo stosowania baricytynibu u dorosłych pacjentów chorujących na IIM (EudraCT Number: 2019-003868-42).

\section{Immunoglobuliny dożylne}

Terapia IVIg zalecana jest chorym na DM w przypadku braku efektu terapii GKS, AZA, MTX i innymi lekami immunosupresyjnymi (ryc. 1). Skuteczność tej formy leczenia jest stosunkowo dobrze udokumentowana. Zalecana dawka IVIg wynosi $2 \mathrm{~g} / \mathrm{kg}$ m.c. przez 2-5 dni raz w miesiącu do uzyskania remisji. Leczenie IVIg przyczynia się do poprawy siły proksymalnych grup mięśni i redukcji aktywności CPK, a także zmniejszenia nasilenia zmian skórnych [37]. W przypadkach opornych na skojarzone leczenie cyklosporyną i prednizonem dodanie IVIg zwiększało szansę uzyskania całkowitej remisji [46]. Opisano również korzystne działanie IVIg w postaci paraneoplastycznej DM, a także u kobiet w ciąży z DM. Poprawę kliniczną uzyskano także w terapii owrzodzeń i zmian naczyniowych opornych na prednizon i inne leki immunosupresyjne. Z uwagi na mniejszą skuteczność w porównaniu z GKS podawanie IVIg nie wydaje się zasadne jako początkowa forma terapii. Po zaprzestaniu leczenia IVIg u części chorych obserwuje się nawrót osłabienia siły mięśni, dlatego dla podtrzymania efektu tej formy terapii u niektórych pacjentów konieczne może być powtarzanie wlewów co 6-12 mie- 


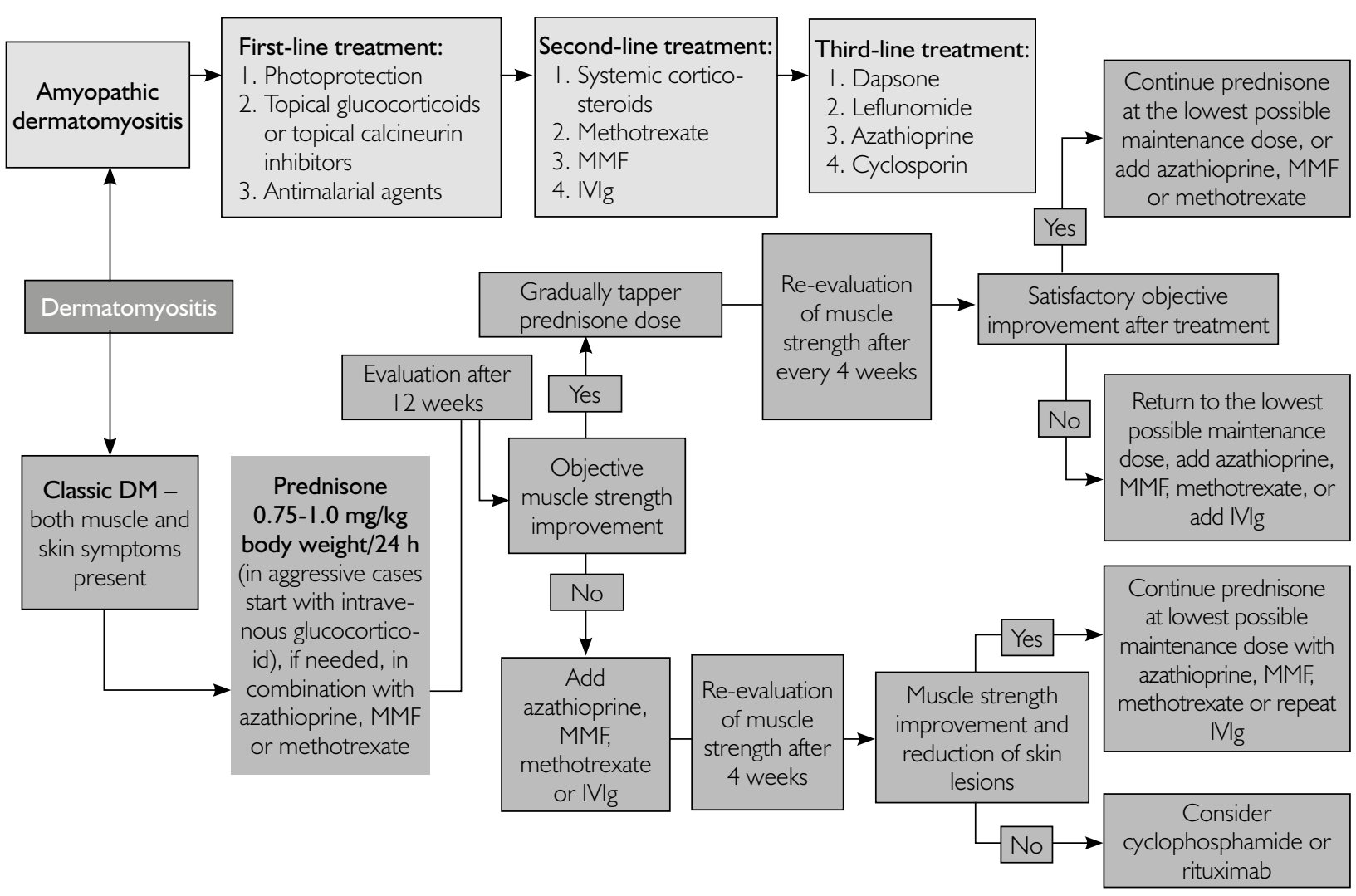

Figure I. Suggested treatment algorithm for dermatomyositis

$\mathrm{IVIg}$ - intravenous immunoglobulin, MMF - mycophenolate mofetil.

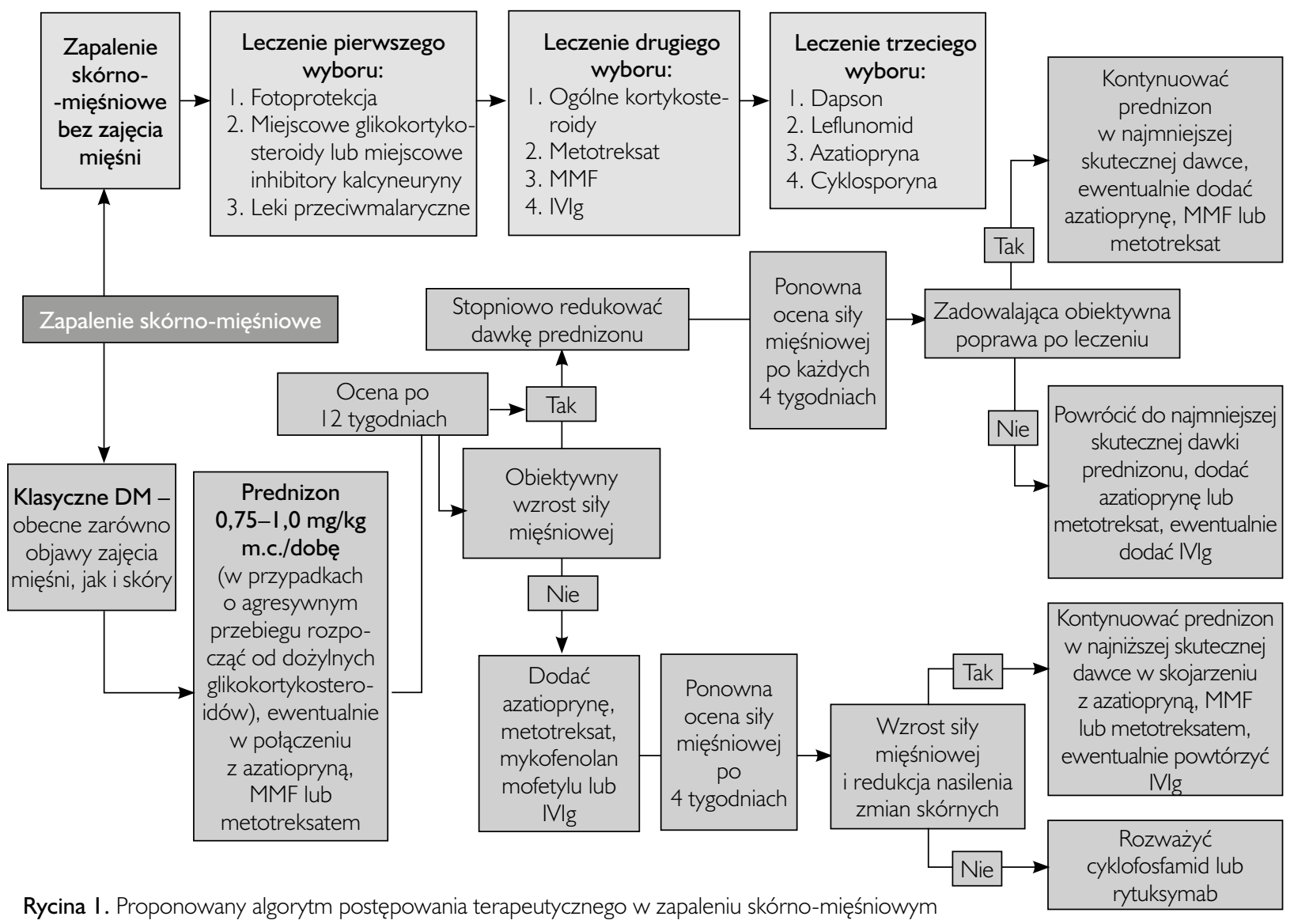

$\mathrm{IVlg}$ - dożylne immunoglobuliny, MMF - mykofenolan mofetylu. 
DM therapy. Placebo-controlled studies have not confirmed the efficacy of this form of treatment, and currently rituximab is not a more widely recommended drug in the treatment of DM, and its use should only be limited to cases that are refractory to other treatments.

\section{Tumor necrosis factor (TNF) inhibitors}

As with rituximab, the first single case reports documented a good effect of both infliximab and etanercept. However, more recent observations, conducted in larger groups of patients, did not confirm a significant benefit of this group of drugs in treatment of DM. Because of the paradoxical possibility of provoking the development of DM, TNF inhibitors are recommended only exceptionally.

\section{PROGNOSIS}

The prognosis in DM has improved significantly since the introduction of systemic glucocorticosteroids and other immunosuppressants. The prognosis in JDM is generally good. In the study conducted in the USA in a group of 662 children, the mortality rate was $0.8 \%$ [49]. The course of JDM is often chronic, recurrent, and leads to muscle wasting and development of cutaneous calcinosis. In children, more often than in adults, the disease becomes generalized and the gastrointestinal tract is affected (motor disorders, ulcerations), both due to vasculopathy and muscle involvement [50]. Prognostic indicators of a severe course of DM in children include erythematous changes around the neckline, "scarf" symptom and arthritis $[1,51]$.

In the case of adults, it is estimated that at least $90 \%$ of patients survive 5 years if there is no accompanying malignancy $[52,53]$. However, treatment results in some patients are not satisfactory. Some cases of DM remain resistant to standard immunosuppressive therapy [45]. Aggressively progressive ILD is the leading cause of death in DM, especially in patients with CADM [54]. In turn, the need to use high doses of glucocorticosteroids contributes to the development of significant side effects. Infections are a frequent complication of glucocorticosteroid therapy and immunosuppressive therapy, including severe AEs in about $25-35 \%$ of patients [37]. Poor prognostic indicators associated with increased mortality include an increase in the ratio of neutrophils to lymphocytes (> 4.8), CRP to albumin level (>0.0735), elevated ESR and a decrease in protein concentration $(<5.5 \mathrm{~g} / \mathrm{dl})[55,56]$. Factors that increase mortality also include: older age, male gender, coexisting cancer, heart involvement, pneumonia, thrombocytopenia and arthritis [1]. sięcy. W Polsce leczenie DM za pomocą IVIg realizowane jest głównie w ramach programu lekowego B67 Ministerstwa Zdrowia „Leczenie immunoglobulinami chorób neurologicznych”, choć jak wskazuje nazwa, program ten jest skierowany do neurologów.

Leczenie IVIg jest stosunkowo dobrze tolerowane i charakteryzuje się małą częstością występowania działań niepożądanych. Do najczęstszych należą: nudności i wymioty, astenia, reakcje nadwrażliwości (rzadko anafilaksja), nefroza osmotyczna, incydenty zakrzepowo-zatorowe i aseptyczne zapalenie opon mózgowo-rdzeniowych [1].

\section{Leczenie biologiczne}

Rytuksymab

Początkowo, na podstawie opisów pojedynczych przypadków, z rytuksymabem wiązano duże nadzieje na skuteczną terapię DM. Badania kontrolowane placebo nie potwierdziły skuteczności tej formy leczenia i obecnie rytuksymab nie jest lekiem szerzej rekomendowanym w DM, a jego zastosowanie powinno być ograniczone jedynie do przypadków opornych na inne metody leczenia.

\section{Inhibitory czynnika martwicy nowotworów (TNF)}

Podobnie jak w przypadku rytuksymabu, pierwsze opisy pojedynczych przypadków dokumentowały dobre efekty stosowania infliksymabu i etanerceptu. Nowsze obserwacje, prowadzone w większych grupach chorych, nie potwierdziły znaczącej korzyści z leczenia DM tą grupą leków. Z uwagi na paradoksalną możliwość sprowokowania rozwoju DM przez inhibitory TNF są one zalecane wyjątkowo.

\section{ROKOWANIE}

Od czasu wprowadzenia GKS stosowanych ogólnie i innych leków immunosupresyjnych rokowanie w DM istotnie się poprawiło. W JDM rokowanie jest $\mathrm{z}$ reguły dobre. W badaniu przeprowadzonym w USA w grupie 662 dzieci śmiertelność wynosiła 0,8\% [49]. Przebieg JDM często jest przewlekły, nawrotowy i prowadzi do zaników mięśni oraz rozwoju wapnicy skóry. U dzieci częściej niż u pacjentów dorosłych dochodzi także do uogólnienia procesu chorobowego i zajęcia przewodu pokarmowego (zaburzenia motoryki, owrzodzenia) zarówno wskutek waskulopatii, jak i zajęcia mięśni [50]. Do wskaźników prognostycznych ciężkiego przebiegu DM u dzieci należą: zmiany rumieniowe w okolicy mostka, objaw szala i zapalenie stawów $[1,51]$.

W przypadku osób dorosłych ocenia się, że jeśli nie stwierdza się towarzyszącego nowotworu złośliwego, 5 lat przeżywa co najmniej $90 \%$ chorych $[52,53]$. Wyniki leczenia u części pacjentów nie są jednak zadowalające. Niektóre przypadki DM są oporne na standardowe le- 


\section{CONCLUSIONS}

Dermatomyositis is a heterogeneous disease characterized by rich symptomatology. Its course, like other systemic connective tissue diseases, is difficult to predict. Broadness of the clinical presentation, as well as different responses of individual symptoms to the applied treatment, pose a great therapeutic challenge, in particular in terms of maintenance treatment. Determination of the panel of antibodies, the specificity of which is often related to the clinical phenotype of the disease, may be helpful in determining the prognosis, including selection of the treatment method. Optimal management of DM, both in children and adults, has not yet been fully established because of rarity of this disease and a small number of standardized clinical trials assessing individual therapeutic methods and procedures of diagnosis and therapy. During treatment, regular check-ups have to be kept in mind, to exclude lung involvement, cancer, as well as overlapping other autoimmune disease. It is also necessary to monitor side effects of the drugs used.

The aim of the presented recommendations is to support doctors in optimizing care for patients with DM and to provide patients with appropriate medical assistance, adapted to the severity of the disease and available therapeutic options. It should be noted that the treating physician must always adjust his/ her diagnostic and therapeutic decisions individually to the patient's current needs, taking into account the patient's current clinical condition and current scientific reports.

\section{CONFLICT OF INTEREST}

The authors declare no conflict of interest. czenie immunosupresyjne [45]. Agresywnie postępująca ILD stanowi główną przyczynę zgonów w DM, zwłaszcza u chorych na CADM [54]. Konieczność stosowania wysokich dawek GKS przyczynia się do rozwoju znaczących objawów ubocznych. Częstym powikłaniem glikokortykosteroidoterapii i leczenia immunosupresyjnego są infekcje, u około 25-35\% pacjentów o ciężkim przebiegu [37]. Złymi wskaźnikami prognostycznymi, związanymi ze zwiększoną śmiertelnością, są wzrost stosunku liczby neutrofilów do limfocytów $(>4,8)$, stężenia CRP do stężenia albumin (>0,0735), przyspieszenie OB i obniżenie stężenia białka $(<5,5 \mathrm{~g} / \mathrm{dl})[55,56]$. Do czynników zwiększających śmiertelność należą także: starszy wiek, płeć męska, współistniejąca choroba nowotworowa, zajęcie serca, odma śródpiersia, trombocytopenia i zapalenie stawów [1].

\section{PODSUMOWANIE}

Zapalenie skórno-mięśniowe jest heterogennym schorzeniem o bogatej symptomatologii, a jego przebieg, podobnie jak innych układowych chorób tkanki łącznej, jest trudny do przewidzenia. Bogactwo obrazu klinicznego, a także różna odpowiedź poszczególnych objawów na stosowane leczenie powodują duże trudności terapeutyczne, dotyczące przede wszystkim leczenia podtrzymującego. Pomocne przy ustalaniu rokowania i doborze metody leczenia może być oznaczanie panelu przeciwciał, których specyficzność nierzadko jest związana $\mathrm{z}$ fenotypem klinicznym choroby. Optymalne postępowanie w DM zarówno u dzieci, jak i osób dorosłych nie zostało dotychczas w pełni ustalone ze względu na rzadkie występowanie tej jednostki chorobowej oraz małą liczbę wystandaryzowanych badań klinicznych oceniających poszczególne metody terapeutyczne i schematy postępowania diagnostyczno-leczniczego. W czasie leczenia należy pamiętać o regularnym wykonywaniu badań kontrolnych w celu wykluczenia zajęcia płuc, podłoża nowotworowego choroby, jak również nakładającego się innego schorzenia autoimmunologicznego. Konieczne jest również monitorowanie objawów ubocznych stosowanych leków.

Celem przedstawionych rekomendacji jest wsparcie lekarzy w optymalizacji opieki nad chorymi na DM i zapewnieniu pacjentom odpowiedniej pomocy lekarskiej, dostosowanej do ciężkości choroby i dostępnych możliwości terapeutycznych. Należy zaznaczyć, że lekarz prowadzący leczenie musi każdorazowo dostosować swoje decyzje diagnostyczne i terapeutyczne indywidualnie do bieżących potrzeb chorego, uwzględniając jego aktualny stan kliniczny, a także opierając się na bieżących doniesieniach naukowych. 


\section{KONFLIKT INTERESÓW}

Autorzy nie zgłaszają konfliktu interesów.

\section{References Piśmiennictwo}

1. Samotij D., Szczęch J., Reich A.: Diagnostic and therapeutic advances in dermatomyositis. Dermatol Rev 2015, 102, 183-197.

2. Lundberg I.E., Tjärnlund A., Bottai M., Werth V.P., Pilkington C., de Visser M., et al.: 2017 European League Against Rheumatism/American College of Rheumatology classification criteria for adult and juvenile idiopathic inflammatory myopathies and their major subgroups. Arthritis Rheumatol 2017, 69, 2271-2282.

3. Findlay A.R., Goyal N.A., Mozaffar T.: An overview of polymyositis and dermatomyositis. Muscle Nerve 2015, 51, 638-656.

4. Smith G.P., Argobi Y.: Pruritus in autoimmune connective tissue diseases. Dermatol Clin 2018, 36, 267-275.

5. Shirani Z., Kucenic M.J., Carroll C.L., Fleischer A.B. Jr, Feldman S.R., Yosipovitch G., et al.: Pruritus in adult dermatomyositis. Clin Exp Dermatol 2004, 29, 273-276.

6. Didona D., Juratli H.A., Scarsella L., Eming R., Hertl M.: The polymorphous spectrum of dermatomyositis: classic features, newly described skin lesions, and rare variants. Eur J Dermatol 2020, 30, 229-242.

7. Diplomatico M., Ametrano O., Errico M.E., Mauro A., Rega R., Sottile R.: Wong-type dermatomyositis: an extremely rare disease in childhood. Dermatol Pract Concept 2019, 9, 325-326.

8. Sunderkötter C., Nast A., Worm M., Dengler R., Dörner T., Ganter H., et al.: Guidelines on dermatomyositis - excerpt from the interdisciplinary S2k guidelines on myositis syndromes by the German Society of Neurology. J Dtsch Dermatol Ges 2016, 14, 321-338.

9. Betteridge Z., McHugh N.: Myositis-specific autoantibodies: an important tool to support diagnosis of myositis. J Intern Med 2016, 280, 8-23.

10. Gofrit S.G., Yonath H., Lidar M., Shoenfeld Y., Kivity S.: The clinical phenotype of patients positive for antibodies to myositis and myositis-related disorders. Clin Rheumatol 2018, 37, 1257-1263.

11. Hozumi H., Fujisawa T., Nakashima R., Johkoh T., Sumikawa H., Murakami A., et al.: Comprehensive assessment of myositis-specific autoantibodies in polymyositis/dermatomyositis-associated interstitial lung disease. Respir Med 2016, 121, 91-99.

12. Ang C.C., Anyanwu C.O., Robinson E., Okawa J., Feng R., Fujimoto M., et al.: Clinical signs associated with an increased risk of interstitial lung disease: a retrospective study of 101 patients with dermatomyositis. Br J Dermatol 2017, 176, 231-233.

13. Chaisson N.F., Paik J., Orbai A.M., Casciola-Rosen L., Fiorentino D., Danoff S., et al.: A novel dermato-pulmonary syndrome associated with MDA-5 antibodies: report of 2 cases and review of the literature. Medicine (Baltimore) 2012, 91, $220-228$.

14. Lega J.C., Reynaud Q., Belot A., Fabien N., Durieu I., Cottin V.: Idiopathic inflammatory myopathies and the lung. Eur Respir Rev 2015, 24, 216-238.

15. Sato S., Hoshino K., Satoh T., Fujita T., Kawakami Y., Fujita T., et al.: RNA helicase encoded by melanoma differentiation-associated gene 5 is a major autoantigen in patients with clinically amyopathic dermatomyositis: association with rapidly progressive interstitial lung disease. Arthritis Rheum 2009, 60, 2193-2200.

16. Yamaoka T., Doi C., Yokomi A., Tanemura A., Murota H., Tani M., et al.: Anti-MDA5 antibody-positive dermatomyositis with lethal progressive interstitial lung disease and advanced gastric cancer. Eur J Dermatol 2014, 24, 490-491.

17. Hamaguchi Y., Kuwana M., Hoshino K., Hasegawa M., Kaji K., Matsushita T., et al.: Clinical correlations with dermatomyositis-specific autoantibodies in adult Japanese patients with dermatomyositis: a multicenter cross-sectional study. Arch Dermatol 2011, 147, 391-398.

18. Casciola-Rosen L., Mammen A.L.: Myositis autoantibodies. Curr Opin Rheumatol 2012, 24, 602-608.

19. Nakashima R.: Clinical significance of myositis-specific autoantibodies. Immunol Med 2018, 41, 103-112.

20. Hengstman G.J., ter Laak H.J., Vree Egberts W.T., Lundberg I.E., Moutsopoulos H.M., Vencovsky J., et al.: Anti-signal recognition particle autoantibodies: marker of a necrotising myopathy. Ann Rheum Dis 2006, 65, 1635-1638.

21. Binns E.L., Moraitis E., Maillard S., Tansley S., McHugh N., Jacques T.S., et al.: Effective induction therapy for anti-SRP associated myositis in childhood: a small case series and review of the literature. Pediatr Rheumatol Online J 2017, 15, 77.

22. Trallero-Araguas E., Rodrigo-Pendas J.A., Selva-O'Callaghan A., Martínez-Gómez X., Bosch X., Labrador-Horrillo M., et al.: Usefulness of anti-p155 autoantibody for diagnosing cancer-associated dermatomyositis. A systematic review and meta-analysis. Arthritis Rheum 2012, 64, 523-532.

23. Mugii N., Hasegawa M., Matsushita T., Hamaguchi Y., Oohata S., Okita H., et al.: Oropharyngeal dysphagia in dermatomyositis: associations with clinical and laboratory features including autoantibodies. PLoS One 2016, 11, e0154746.

24. Chinoy H., Fertig N., Oddis C.V., Ollier W.E., Cooper R.G.: The diagnostic utility of myositis autoantibody testing for predicting the risk of cancer-associated myositis. Ann Rheum Dis 2007, 66, 1345-1349.

25. Fujimoto M., Matsushita T., Hamaguchi Y., Kaji K., Asano Y., Ogawa F., et al.: Autoantibodies to small ubiquitin-like modifier activating enzymes in Japanese patients with dermatomyositis: comparison with a UK Caucasian cohort. Ann Rheum Dis 2013, 72, 151-153.

26. Kooistra L., Ricotti C., Galimberti F., Gota C., Fernandez A.P.: Malignancy-associated dermatomyositis: retrospective case-control study from a single tertiary care center. J Am Acad Dermatol 2018, 79, 152-155. 
27. Leatham H., Schadt C., Chisolm S., Fretwell D., Chung L., Callen J.P., et al.: Evidence supports blind screening for internal malignancy in dermatomyositis: Data from 2 large US dermatology cohorts. Medicine (Baltimore) 2018, 97, e9639.

28. Lu X., Yang H., Shu X., Chen F., Zhang Y., Zhang S., et al.: Factors predicting malignancy in patients with polymyositis and dermatomyostis: a systematic review and meta-analysis. PLoS One 2014, 9, e94128.

29. Aggarwal R., Rider L.G., Ruperto N., Bayat N., Erman B., Feldman B.M., et al.: 2016 American College of Rheumatology/ European League Against Rheumatism criteria for minimal, moderate, and major clinical response in adult dermatomyositis and polymyositis: An International Myositis Assessment and Clinical Studies Group/Paediatric Rheumatology International Trials Organisation Collaborative Initiative. Ann Rheum Dis 2017, 76, 792-801.

30. Rider L.G., Aggarwal R., Pistorio A., Bayat N., Erman B., Feldman B.M., et al.: 2016 American College of Rheumatology/ European League Against Rheumatism Criteria for Minimal, Moderate, and Major Clinical Response in Juvenile Dermatomyositis: An International Myositis Assessment and Clinical Studies Group/Paediatric Rheumatology International Trials Organisation Collaborative Initiative. Ann Rheum Dis 2017, 76, 78291.

31. Huber A.M., Robinson A.B., Reed A.M., Abramson L., Bout-Tabaku S., Carrasco R., et al.: Consensus treatments for moderate juvenile dermatomyositis: beyond the first two months. Results of the second Childhood Arthritis and Rheumatology Research Alliance consensus conference. Arthritis Care Res (Hoboken) 2012, 64, 546-553.

32. Ringold S., Nigrovic P.A., Feldman B.M., Tomlinson G.A., von Scheven E., Wallace C.A., et al.: The childhood arthritis and rheumatology research alliance consensus treatment plans: toward comparative effectiveness in the pediatric rheumatic diseases. Arthritis Rheumatol 2018, 70, 669-678.

33. Kim S., Kahn P., Robinson A.B., Lang B., Shulman A., Oberle E.J., et al.: Childhood Arthritis and Rheumatology Research Alliance consensus clinical treatment plans for juvenile dermatomyositis with skin predominant disease. Pediatr Rheumatol Online J 2017, 15, 1.

34. Enders F.B., Bader-Meunier B., Baildam E., Constantin T., Dolezalova P., Feldman B.M., et al.: Consensus-based recommendations for the management of juvenile dermatomyositis. Ann Rheum Dis 2017, 76, 329-340.

35. Huber A.M., Kim S., Reed A.M., Carrasco R., Feldman B.M., Hong S.D., et al.: Childhood Arthritis and Rheumatology Research Alliance consensus clinical treatment plans for juvenile dermatomyositis with persistent skin rash. J Rheumatol 2017, 44, 110-116.

36. Spencer C.H., Rouster-Stevens K., Gewanter H., Syverson G., Modica R., Schmidt K., et al.: Biologic therapies for refractory juvenile dermatomyositis: five years of experience of the Childhood Arthritis and Rheumatology Research Alliance in North America. Pediatr Rheumatol Online J 2017, 15, 50.

37. Marie I., Hatron P.Y., Dominique S., Cherin P., Mouthon L., Menard J.F.: Short-term and long-term outcomes of interstitial lung disease in polymyositis and dermatomyositis: a series of 107 patients. Arthritis Rheum 2011, 63, 3439-3447.

38. Dalakas M.C.: Immunotherapy of myositis: issues, concerns and future prospects. Nat Rev Rheumatol 2010, 6, $129-137$.

39. Hornung T., Ko A., Tüting T., Bieber T., Wenzel J.: Efficacy of low-dose methotrexate in the treatment of dermatomyositis skin lesions. Clin Exp Dermatol 2012, 37, 139-142.

40. Chen K.L., Zeidi M., Werth V.P.: Recent advances in pharmacological treatments of adult dermatomyositis. Curr Rheumatol Rep 2019; 21: 53.

41. Barba T., Fort R., Cottin V., Provencher S., Durieu I., Jardel S., et al.: Treatment of idiopathic inflammatory myositis associated interstitial lung disease: a systematic review and meta-analysis. Autoimmun Rev 2019, 18, 113-122.

42. Edge J.C., Outland J.D., Dempsey J.R., Callen J.P.: Mycophenolate mofetil as an effective corticosteroid-sparing therapy for recalcitrant dermatomyositis. Arch Dermatol 2006, 142, 65-69.

43. Pisoni C.N., Cuadrado M.J., Khamashta M.A., Hughes G.R., D'Cruz D.P.: Mycophenolate mofetil treatment in resistant myositis. Rheumatology (Oxford) 2007, 46, 516-518

44. Morganroth P.A., Kreider M.E., Werth V.P.: Mycophenolate mofetil for interstitial lung disease in dermatomyositis. Arthritis Care Res 2010, 62, 1496-1501.

45. Kohsaka H., Mimori T., Kanda T., Shimizu J., Sunada Y., Fujimoto M., et al.: Treatment consensus for management of polymyositis and dermatomyositis among rheumatologists, neurologists and dermatologists. Mod Rheumatol 2019, 29 , e1-e19.

46. Danieli M.G., Malcangi G., Palmieri C., Logullo F., Salvi A., Piani M., et al.: Cyclosporin A and intravenous immunoglobulin treatment in polymyositis/dermatomyositis. Ann Rheum Dis 2002, 61, 37-41.

47. Kim H., Dill S., O'Brien M., Vian L., Li X., Manukyan M., et al.: Janus kinase (JAK) inhibition with baricitinib in refractory juvenile dermatomyositis. Ann Rheum Dis 2020; annrheumdis-2020-218690 [Online ahead of print].

48. Lam C., Vleugels R.A.: Management of cutaneous dermatomyositis. Dermatol Ther 2012, 25, 112-134.

49. Hashkes P.J., Wright B.M., Lauer M.S., Worley S.E., Tang A.S., Roettcher P.A., et al.: Mortality outcomes in pediatric rheumatology in the US. Arthritis Rheum 2010, 62, 599-608.

50. Hoeltzel M.F., Oberle E.J., Robinson A.B., Agarwal A., Rider L.G.: The presentation, assessment, pathogenesis, and treatment of calcinosis in juvenile dermatomyositis. Curr Rheumatol Rep 2014, 16, 467.

51. Kobayashi I., Akioka S., Kobayashi N., Iwata N., Takezaki S., Nakaseko H., et al.: Clinical practice guidance for juvenile dermatomyositis (JDM) 2018-Update. Mod Rheumatol 2020, 30, 411-423.

52. Yu K.H., Wu Y.J., Kuo C.F., See L.C., Shen Y.M., Chang H.C., et al.: Survival analysis of patients with dermatomyositis and polymyositis: analysis of 192 Chinese cases. Clin Rheumatol 2011, 30, 1595-1601.

53. Danieli M.G., Gambini S., Pettinari L., Logullo F., Veronesi G., Gabrielli A.: Impact of treatment on survival in polymyositis and dermatomyositis. A single-centre long-term follow-up study. Autoimmun Rev 2014, 13, 1048-1054.

54. Sugiyama Y., Yoshimi R., Tamura M., Takeno M., Kunishita Y., Kishimoto D., et al.: The predictive prognostic factors for polymyositis/dermatomyositis-associated interstitial lung disease. Arthritis Res Ther 2018, 20, 7. 
55. Ha Y.J., Hur J., Go D.J., Kang E.H., Park J.K., Lee E.Y., et al.: Baseline peripheral blood neutrophil-to-lymphocyte ratio could predict survival in patients with adult polymyositis and dermatomyositis: a retrospective observational study. PLoS One 2018, 13, e0190411.

56. Wu C., Wang Q., He L., Yang E., Zeng X.: Hospitalization mortality and associated risk factors in patients with polymyositis and dermatomyositis: a retrospective case-control study. PLoS One 2018, 13, e0192491.

Received: 13.04 .2021

Accepted: 18.04.2021

Otrzymano: $13.04 .2021 \mathrm{r}$.

Zaakceptowano: $18.04 .2021 \mathrm{r}$.

Reich A., Lis-Święty A., Krasowska D., Maj J., Narbutt J., Sysa-Jędrzejowska A., Wojas-Pelc A., Woźniacka A., Rudnicka L.:

Dermatomyositis. Diagnostic and therapeutic recommendations of the Polish Dermatological Society.

Dermatol Rev/Przegl Dermatol 2021, 108, 85-104. DOI: https://doi.org/10.5114/dr.2021.107278. 